\title{
The Effect of Nanofillers on the Functional Properties of Biopolymer-Based Films: A Review
}

\author{
Ewelina Jamróz $^{1}\left(\right.$, Piotr Kulawik ${ }^{2}\left(\mathbb{D}\right.$ and Pavel Kopel ${ }^{3,4, *(1)}$ \\ 1 Institute of Chemistry, University of Agriculture in Cracow, Balicka Street 122, PL-30-149 Kraków, Poland; \\ ewelina.jamroz@urk.edu.pl \\ 2 Department of Animal Products Processing, University of Agriculture, Balicka Street 122, \\ PL-30-149 Kraków, Poland; kulawik.piotr@gmail.com \\ 3 Department of Chemistry and Biochemistry, Faculty of AgriSciences, Mendel University in Brno, \\ Zemedelska 1, CZ-613 00 Brno, Czech Republic \\ 4 Central European Institute of Technology, Brno University of Technology, Purkynova 123, \\ CZ-612 00 Brno, Czech Republic \\ * Correspondence: paulko@centrum.cz; Tel.: +420-545-133-350
}

Received: 21 March 2019; Accepted: 9 April 2019; Published: 12 April 2019

\begin{abstract}
Waste from non-degradable plastics is becoming an increasingly serious problem. Therefore, more and more research focuses on the development of materials with biodegradable properties. Bio-polymers are excellent raw materials for the production of such materials. Bio-based biopolymer films reinforced with nanostructures have become an interesting area of research. Nanocomposite films are a group of materials that mainly consist of bio-based natural (e.g., chitosan, starch) and synthetic (e.g., poly(lactic acid)) polymers and nanofillers (clay, organic, inorganic, or carbon nanostructures), with different properties. The interaction between environmentally friendly biopolymers and nanofillers leads to the improved functionality of nanocomposite materials. Depending on the properties of nanofillers, new or improved properties of nanocomposites can be obtained such as: barrier properties, improved mechanical strength, antimicrobial, and antioxidant properties or thermal stability. This review compiles information about biopolymers used as the matrix for the films with nanofillers as the active agents. Particular emphasis has been placed on the influence of nanofillers on functional properties of biopolymer films and their possible use within the food industry and food packaging systems. The possible applications of those nanocomposite films within other industries (medicine, drug and chemical industry, tissue engineering) is also briefly summarized.
\end{abstract}

Keywords: biopolymer films; nanofillers; functional properties; film mechanical properties; film permeability; antimicrobial activity; nanocomposite materials; food packaging systems

\section{Introduction}

Nanocomposite films are a new generation of packaging materials with combination of bio-based polymer and fillers that have at least one nanometer scale dimension. In nanocomposite films, the biopolymer acts as a matrix, while the nanofillers are dispersed therein to improve the functional properties. Nanocomposites have a set of improved properties, such as mechanical, antimicrobial, or physical properties. These properties do not occur naturally in the biopolymers themselves, therefore they are gained due to addition of nanocomposites [1]. The components of biopolymer films are characterized by high availability and good biodegradability. However, one-component films have relatively poor mechanical properties and high water vapor permeability, which may cause them not to be of sufficient quality to be used as packaging materials. This can be reduced by mixing two biopolymers with one another [2]. Currently, a novel method to improve the properties of biopolymer 
films is the use of nanofillers, which can fulfill not only the reinforcing function but also could act as an active ingredient. In recent years, the concept of active agents for biopolymer films has received much more attention. Such active ingredients in biopolymer films can extend the shelf-life of food products, through exhibiting antimicrobial and/or antioxidant activities [3,4]. The preservative effect of biopolymer films with nanofillers have been reported for the whole spectrum of food products including vegetables and fruits, mushrooms, dairy products, meat and meat products, and fish and other seafood [5-15]. The development of nanotechnology has led to the design of nanocomposite film materials in which nanofillers play an active role. The aim of this review is to summarize recent advances and achievements regarding the addition of nanofillers-such as clay, metals, metal oxides, polymer nanoparticles, nanocellulose, etc.-into biopolymer films with a focus on their functional properties and a possible use in food packaging systems. Additionally, this review shows recent applications of biopolymer films with nanofillers on wound dressing, drug, and enzyme delivery systems and tissue engineering.

\section{Types of Biopolymers and Nanofillers}

New trends and perspectives in nanotechnology, have facilitated the path to use nanofillers as active agents in the packaging industry. This solution applies to the production of biodegradable packaging material, which is based on biopolymers and nanofillers. This type of nanocomposite material is not capable of replacing synthetic packaging materials, because it has many disadvantages, i.e., weak mechanical properties, too high hydrophilicity, and susceptibility to decomposition. However, they are interesting alternatives to plastic materials and can be used for example in areas where plastic recovery is not economically feasible [16].

Currently, there is a growing interest in the combination of biopolymer and nanofiller-based materials. Nanofillers can have different shapes and sizes, but their individual particles size is, by definition of the nanomaterials, below $100 \mathrm{~nm}$ [1]. The size of nanofillers is very beneficial for nanocomposite materials because they are based on a large surface area which leads to a large interphase or boundary area between the biopolymer matrix and nanofiller. Due to such interaction, the biopolymer matrix is modified, which could contribute to the improvement of mechanical, thermal, and barrier properties of bionanocomposite materials [17].

\subsection{Types of Biopolymers Matrix}

Bio-based polymers, which are considered the matrix base during preparation of nanocomposite films, have many advantages. They are renewable, biodegradable, multi-functional, and biocompatible [18].

Bio-based polymers can be classified into two major categories:

1. Natural bio-based polymers, including:

- $\quad$ polymers extracted from agricultural resources:

- polysaccharides:

- neutral: e.g., cellulose, hemicellulose, starch

- cationic: e.g., chitin, chitosan

- anionic: alginic acid, hyaluronic acid

- of bacterial origin: e.g., pullulan, carrageenan;

- proteins: e.g., gelatin and whey protein;

2. Other bio-based polymers: e.g., lipid, lignin, natural rubber, urushiol, DNA, etc. polymers produced directly from microorganisms bacterial cellulose; polyhydroxyalkanoates, poly$\varepsilon$-caprolactones.

3. Synthetic bio-based polymers, including: 
- natural-based or bio-based synthetic polymers, the monomers of which are derived from renewable resources (e.g., poly(lactic acid)-PLA);

- partially bio-based polymers such as polyethylene (PE), poly(ethylene terephtalate) (PET) and polyamide (PA), etc. [19-22].

Among biopolymers, starch and chitosan are the most often used polysaccharides in the production of biopolymer films. Chitosan is a highly interesting film forming base due to its biological (antimicrobial and antioxidant activity) and physical (thermal or mechanical) properties [23]. The use of starch as film forming coatings eliminates the problem of environmental pollution because it is an economical, non-toxic, and environmentally friendly biopolymer. However, starch's poor mechanical properties, moisture sensitivity, and weak barrier properties restricts its use as a commercial packaging materials [24]. Pullulan is a neutral polysaccharide obtained from the fermentation medium of the fungus-like yeast Aureobasidium pullulans [25]. It has superb optical properties, and applications of this type of non-toxic, biodegradable polymer for use in novel optical materials may be encouraging [26].

Proteins such as gelatin are also used in the preparation of films. However, proteins have poor mechanical properties and very high sensitivity to moisture which are problems in the commercialization of this type of film [27]. Beeswax is a good barrier against moisture migration, because it is hydrophobic and has a firmly packed crystalline structure, which is why it is often added to a polysaccharide and protein matrix to reduce the parameters of water vapor permeability of biopolymer films [28,29].

Poly(lactic acid) or polylactide is derived from renewable biomass products and wastes such as corn starch. This polymer is compostable, non-toxic, biocompatible, thermoplastic, and has desirable mechanical properties [30]. However, PLA has some limitations for packaging applications such as weak water vapor permeability, low thermal stability, and high rigidity [31]. Polyvinyl alcohol (PVA) is a non-toxic polymer, which has excellent chemical resistance and physical properties [32]. The major drawback of this synthetic polymer is its low mechanical strength [33]. Polyhydroxyalkanoates (PHAs) are a family of biopolyesters produced by a wide variety of bacteria, which are often used as a film component [34]. Due to its biodegradability and compatibility with various polymers and nanofillers, poly ( $\varepsilon$-caprolactone) (PCL) has recently gained interest [35]. However, due to the hydrophobicity and crystallinity of this polymer, PCL undergoes very slow biodegradation as a result microorganisms in the environment [36].

As noted, there are many types of biopolymer films with each having their own advantages and disadvantages (Table 1). Some drawbacks of the polysaccharide or protein films can be overcome. Blending the different biopolymers together is one of the promising methods of improving the functional properties of biopolymer-based films $[37,38]$. The second is to use cross-linking of biopolymer films with various nanofillers. 
Table 1. Advantages and disadvantages of biopolymer films.

\begin{tabular}{|c|c|c|}
\hline $\begin{array}{l}\text { Type of Biopolymer } \\
\text { Film }\end{array}$ & Advantages & Disadvantages \\
\hline cellulose-based films & $\begin{array}{l}\text { tasteless, odorless, resistant to oil and } \\
\text { fat, hydrophilic nature [27]; thermal and } \\
\text { chemical stability [39] }\end{array}$ & $\begin{array}{l}\text { hardly dissolves or melts due to high } \\
\text { crystallinity [40]; non antimicrobial } \\
\text { activity [41] }\end{array}$ \\
\hline $\begin{array}{l}\text { chitin and } \\
\text { chitosan-based films }\end{array}$ & $\begin{array}{l}\text { good } \mathrm{CO}_{2} \text { barrier properties, } \\
\text { antimicrobial activity [42] }\end{array}$ & $\begin{array}{l}\text { non antioxidant and antifungal } \\
\text { activity [43]; limited oxygen and water } \\
\text { impediment ability [44] }\end{array}$ \\
\hline starch-based films & $\begin{array}{c}\text { odorless, tasteless, good } \mathrm{O}_{2} \text { and } \mathrm{CO}_{2} \\
\text { barrier properties [45] }\end{array}$ & $\begin{array}{c}\text { poor water vapor barrier [46] and } \\
\text { tensile properties [47] }\end{array}$ \\
\hline pectin-based films & excellent oxygen barring capacity [48] & $\begin{array}{l}\text { high water vapor permeability [49]; } \\
\text { poor mechanical performance [48] }\end{array}$ \\
\hline pullulan-based films & $\begin{array}{l}\text { heat-sealable [50]; highly impermeable } \\
\text { to both oil and oxygen [51]; excellent } \\
\text { mechanical properties and a low } \\
\text { permeability to oil and oxygen [52] }\end{array}$ & $\begin{array}{l}\text { low solubility [50]; hydrophilic } \\
\text { nature [52] }\end{array}$ \\
\hline alginate-based films & $\begin{array}{l}\text { good water solubility, gel ability, and } \\
\text { film-forming properties [53] }\end{array}$ & $\begin{array}{l}\text { insufficient mechanical properties and } \\
\text { poor water resistance [54] }\end{array}$ \\
\hline gelatin-based films & $\begin{array}{l}\text { good mechanical and barrier } \\
\text { properties [55] }\end{array}$ & low water vapor permeability [56] \\
\hline $\begin{array}{l}\text { whey protein-based } \\
\text { films }\end{array}$ & $\begin{array}{l}\text { excellent barrier properties to aroma } \\
\text { compounds and oils [27] }\end{array}$ & $\begin{array}{c}\text { hydrophilic nature so it has limitation to } \\
\text { moisture [27] }\end{array}$ \\
\hline lipids-based films & $\begin{array}{l}\text { excellent barriers against moisture } \\
\text { migration [27] }\end{array}$ & $\begin{array}{l}\text { damage the appearance and gloss of the } \\
\text { coated food products [57] }\end{array}$ \\
\hline $\begin{array}{l}\text { bacterial } \\
\text { cellulose-based films }\end{array}$ & $\begin{array}{l}\text { flexibility and excellent mechanical } \\
\text { properties [58] }\end{array}$ & insoluble in water [59] \\
\hline PCL- based films & $\begin{array}{l}\text { high mechanical strength, } \\
\text { biocompatibility, processability, and } \\
\text { permeability [60] }\end{array}$ & highly hydrophobic and crystalline [61] \\
\hline PLA-based films & $\begin{array}{l}\text { environmental friendliness, good } \\
\text { transparency, and biological } \\
\text { compatibility [62] }\end{array}$ & $\begin{array}{l}\text { high hardness, and brittleness, low } \\
\text { strength, and poor thermal stability [63] }\end{array}$ \\
\hline PGA-based films & high mechanical strength [64] & $\begin{array}{l}\text { high degree of crystallinity, a high } \\
\text { melting point, and it is insoluble in } \\
\text { common organic solvents [65] }\end{array}$ \\
\hline PU-based films & $\begin{array}{l}\text { favorable processability, versatile } \\
\text { structure-property relationships, and } \\
\text { excellent elasticity [66] }\end{array}$ & low water resistance and hardness [66] \\
\hline
\end{tabular}

\subsection{Types of Nanofillers}

There are four types of nanofillers: clays, organic, inorganic, and carbon nanostructure. The organic nanofillers include natural biopolymers (e.g. chitosan, cellulose), whereas inorganic agents are either a metal (e.g. silver) or metal oxide (e.g. $\mathrm{ZnO}$ and $\mathrm{TiO}_{2}$ ) [4,67]. Carbon nanostructures can be classified into fullerenes, graphene, carbon nanotubes, and nanofibers [68]. A list of examples of properties of various nanofillers is shown in Table 2. 
Table 2. Recent examples of nanofillers properties.

\begin{tabular}{|c|c|c|}
\hline Type of Nanofillers & Properties Added to the Film & Reference \\
\hline \multicolumn{3}{|c|}{ Clay Nanofillers } \\
\hline \multirow[b]{2}{*}{ MMT, Hal etc. } & UV shielding properties & [69] \\
\hline & Good mechanical stability & \\
\hline \multicolumn{3}{|c|}{ Organic Nanofillers } \\
\hline \multirow{5}{*}{ Nanocellulose } & Blood compatibility & \\
\hline & Antibacterial effect & [71] \\
\hline & Thermal stability & [72] \\
\hline & Good mechanical stability & \\
\hline & Low cytotoxicity & [73] \\
\hline \multirow{4}{*}{ Chitosan nanoparticles } & Biocompatibility & \\
\hline & Biodegradability & [74] \\
\hline & Low toxicity & [75] \\
\hline & Antimicrobial activity & [76] \\
\hline \multicolumn{3}{|c|}{ Inorganic Nanofillers } \\
\hline \multirow{4}{*}{ AgNPs } & Antimicrobial effect & [77] \\
\hline & UV shielding properties & [78] \\
\hline & Antioxidant activity & [79] \\
\hline & Photocatalytic effect & [80] \\
\hline \multirow{2}{*}{ SeNPs } & Antimicrobial effect & [81] \\
\hline & Antioxidant activity & [82] \\
\hline \multirow{2}{*}{ CuNPs } & Antimicrobial effect & [83] \\
\hline & UV shielding properties & [84] \\
\hline SNPs & Antimicrobial effect & [85] \\
\hline \multirow{4}{*}{$\mathrm{TiO}_{2} \mathrm{NPs}$} & Antifouling effect & [86] \\
\hline & Antimicrobial activity & [87] \\
\hline & Photocatalytic activity & [88] \\
\hline & UV shielding properties & [69] \\
\hline \multirow{6}{*}{$\mathrm{ZnO} N P s$} & Antifungal effect & \\
\hline & UV shielding properties & [89] \\
\hline & Antimicrobial effect & [90] \\
\hline & Dielectric properties & \\
\hline & Electromagnetic shielding & \\
\hline & Thermal conductivity & [91] \\
\hline \multirow{4}{*}{$\mathrm{CeO}_{2}$} & Antimicrobial effect & \\
\hline & UV shielding properties & \\
\hline & Flame retardancy & \\
\hline & Wrinkle resistance & [92] \\
\hline \multicolumn{3}{|c|}{ Carbon Nanofillers } \\
\hline \multirow{2}{*}{$\begin{array}{l}\text { Graphene, graphene } \\
\text { oxide, etc. }\end{array}$} & Lightweight & \\
\hline & $\begin{array}{l}\text { Processing benefits, flexibility, resistance to corrosion } \\
\text { Extraordinary electrical, mechanical, and thermal properties }\end{array}$ & [93] \\
\hline
\end{tabular}

The hybrid materials, which are materials made from hybrid of organic and inorganic materials, attracts more and more attention in various fields of research. In comparison to conventional materials, organic-inorganic hybrid materials have features derived from the inorganic part (rigidity, dimensional stability and thermal stability) as well as the properties of organic materials (tenacity and workability) [94]. 


\subsubsection{Clay and Organic Nanofillers}

Natural clays are inexpensive materials and exist as aluminum silicate, which consists of fine-grained minerals. Currently, nanoclays are the most commonly used nanoparticles, and they exist in the form of sheets/platelets, which have at least one dimension in the nanoscale range. The most often used nanoclay is montmorillonite (MMT), which consists of two tetrahedral silica sheets connected to an edge-divided, eight-sided aluminum oxide sheet [16]. Another type of nanoclay is halloysite (Hal), which is a natural aluminosilicate clay mineral with hollow, cylindrical-shaped nanotubes [95]. The strong mechanical properties of Hal have been integrated with the antimicrobial and photocatalytic properties of metal oxides and metal nanoparticles by grafting them on Hal [95-97].

Natural biopolymer nanofibrils, which are composed of various biopolymer moleculesi.e., cellulose, collagen, and chitin—are often used due to their biocompatibility, biodegradability, durability, availability, and unique mechanical properties [98]. Nanocellulose, which is extracted from cellulose, is characterized by the reactive surface of hydroxyl groups and thus can be adapted to different surface properties $[99,100]$. There are three types of cellulose used on the nanoscale as an additive to biopolymer films: nanocrystalline cellulose, nanofibrillated cellulose, and bacterial nanocellulose [100]. These types of nanocellulose differ in their morphology, degree of crystallinity, particle size, and some other properties. These differences result from their sources and various extraction methods used [100]. Nanocrystalline cellulose with its high crystallinity and short-rod shape is also known as cellulose nanocrystals or cellulose nanowhiskers and is usually extracted from cellulose fibrils by acid hydrolysis [101]. The source of cellulose nanocrystals may also affect the functionality of the nanofiller [102].

Nanofibrillated cellulose is extracted from cellulose fibers using mechanical methods. This long, flexible, and tangled nanocellulose is also known as cellulose microfibril, microfibrillated cellulose, cellulose nanofiber, cellulose nanofibril, and nanofibrillar cellulose [100].

Bacterial nanocellulose (BNC), which is mainly extracted from cultures of the Gram-negative bacteria, Gluconacetobacter xylinus, has a higher molecular weight and crystallinity than cellulose from plant sources [103]. The different types of nanocellulose have been incorporated to many biopolymer films [104-107].

Chitosan and chitin nanoparticles obtained respectively from chitosan or chitin have gained attention as nanofillers, due to their attractive surface area, biocompatibility, non-toxicity and film forming ability [108-112]. An important limitation in the use of chitosan nanoparticles is their poor stability. It can be improved by controlling the conditions e.g., by changing the structure with chemical agents. Poor solubility of chitosan nanoparticles is the next limitation, which is a major problem in the encapsulation of hydrophobic drugs [113].

\subsubsection{Inorganic Nanofillers}

Due to their better mechanical, thermal, physical, biological, and chemical properties than bulk materials, nanoparticles (NPs) are an interesting solution as functional agents for biopolymers films. Copper nanoparticles (CuNPs) are known to possess antimicrobial activity on wide spectrum of microbes. Released copper ions have a high redox potential and the ability to destroy and cause apoptosis of microbial cell components [114]. Owing to their excellent physicochemical and biological properties, silver nanoparticles (AgNPs) have gained increasingly more attention for use in wound healing [115], food packaging [116], and in medical applications [117]. Selenium nanoparticles (SeNPs) show significantly reduced toxicity compared to selenium. In addition, SeNPs can be used as a platform for transporting different drugs to target destinations [118].

Metal oxide nanoparticles such as zinc oxide $(\mathrm{ZnO} \mathrm{NPs})$, titanium oxide $\left(\mathrm{TiO}_{2} \mathrm{NPs}\right)$, silica $\left(\mathrm{SiO}_{2} \mathrm{NPs}\right)$, aluminum oxide $\left(\mathrm{Al}_{2} \mathrm{O}_{3} \mathrm{NPs}\right)$, cerium oxide $\left(\mathrm{CeO}_{2} \mathrm{NPs}\right)$, iron oxide $\left(\mathrm{Fe}_{2} \mathrm{O}_{3} \mathrm{NPs}\right)$, and copper oxide ( $\mathrm{CuO} N \mathrm{NP}$ ) have been added to biopolymer films as active nanofillers. $\mathrm{TiO}_{2} \mathrm{NPs}$ and $\mathrm{ZnO}$ NPs have photocatalytic antibacterial properties, caused by reactive oxygen species (ROS) formation after exposure to UV-light [119]. Additionally, ZnO NPs can release zinc ions that damage bacterial 
cells, showing that antimicrobial properties do not have to be dependent on UV exposure [120]. The low hydrophilicity of $\mathrm{TiO}_{2}$ prevents the penetration of moisture into the biopolymer matrix. Moreover, the barrier effect of $\mathrm{TiO}_{2}$ leads to reduction in water vapor permeability [121]. CuO NPs have antimicrobial, antibacterial, and antioxidant activity and exhibit a UV-blocking effect [122,123]. Tin oxide $\left(\mathrm{SnO}_{2}\right)$ nanoparticles have electrical, thermal, mechanical and gas barrier properties [124,125]. The addition of non-toxic and neutral $\mathrm{Al}_{2} \mathrm{O}_{3} \mathrm{NPs}$ to the biopolymer matrix provides a wide range of promising properties due to its small particles, significant surface area, and good activity [126,127].

\subsubsection{Carbon Nanofillers}

Graphene-based materials have gained attention due to their properties which include excellent mechanical properties and substantial electron mobility. Graphene, in comparison to other carbon-based nanomaterials (for example carbon nanotubes), is characterized by a larger surface area that could facilitate interactions with the polymer matrix $[128,129]$. Graphene oxide $(\mathrm{GO})$ is the most promising nanofiller, among the graphene-family nanomaterials, because it has a lower tendency to agglomerate than pristine graphene [130]. The biggest limitations, for the use of GO, are its intrinsic zero band-gap energy and low solubility in organic and aqueous solvents [131]. The chemical functionalization of graphene oxide leads to its modification and thus increases the possibilities of its potential application. Reduced GO (RGO) has very good mechanical, physical, electrical, and thermal properties, which makes it attractive nanofiller in biopolymer films [132].

\subsubsection{Other Nanofillers}

Semiconductor quantum dots (QDs) are attracting increasing attention due to their optical properties and high photostability [133]. Due to their strong tendency of oxidation and agglomeration, it is desirable to improve the compatibility and stability of this type of nanofillers in biopolymers [134]. Graphene quantum dots (GQDs) incorporated in biopolymer films have advantages such as availability, biodegradability, low price, and low production cost, making the nanocomposite films a preferred candidate for use in optoelectronics applications [135].

\section{Effects of Nanofillers on the Functional Properties of Biopolymer-Based Films}

The graphical illustration of nanofillers use within the biopolymer matrix along with their functional properties is presented in Figure 1.

\subsection{Effects of Nanofillers on the Physical Properties of Polymer-Based Films}

Water resistance is an important functional parameter of biopolymer films. In many studies, water resistance of the films is evaluated by their water solubility, swelling degree, water content, and water vapor permeability $[87,136]$.

The addition of nanofillers decreases the solubility of biopolymer films due to the ratio of dimensions and crystalline areas of the fillers $[87,137]$. Noshirvani and co-workers $(2018)$ confirmed that the lower solubility of the nanocomposite films is caused by the hydrogen bond between the hydroxyl groups of starch, PVA, and cellulose nanocrystals. The three-dimensional network generated leads to the strengthening of the network and reduces its solubility [138]. The same trend was observed in kefiran-caboxymethyl cellulose films with $\mathrm{CuO}$ NPs [139] and in kefiran films with $\mathrm{Al}_{2} \mathrm{O}_{3} \mathrm{NPs}$ [127]. Moreover, the type of nanoparticles also plays an important role in the solubility of the film. A decrease in the solubility of the film can be attributed to the very low solubility of the nanoparticles compared to the polymer chains, which leads to a reduction in the hydrophilicity of the biopolymer matrix [121]. The interactions between halloysite nanoclay and soluble soybean polysaccharide caused a decrease in water solubility due to reduction in the availability of hydroxyl groups to interact with water [140]. 


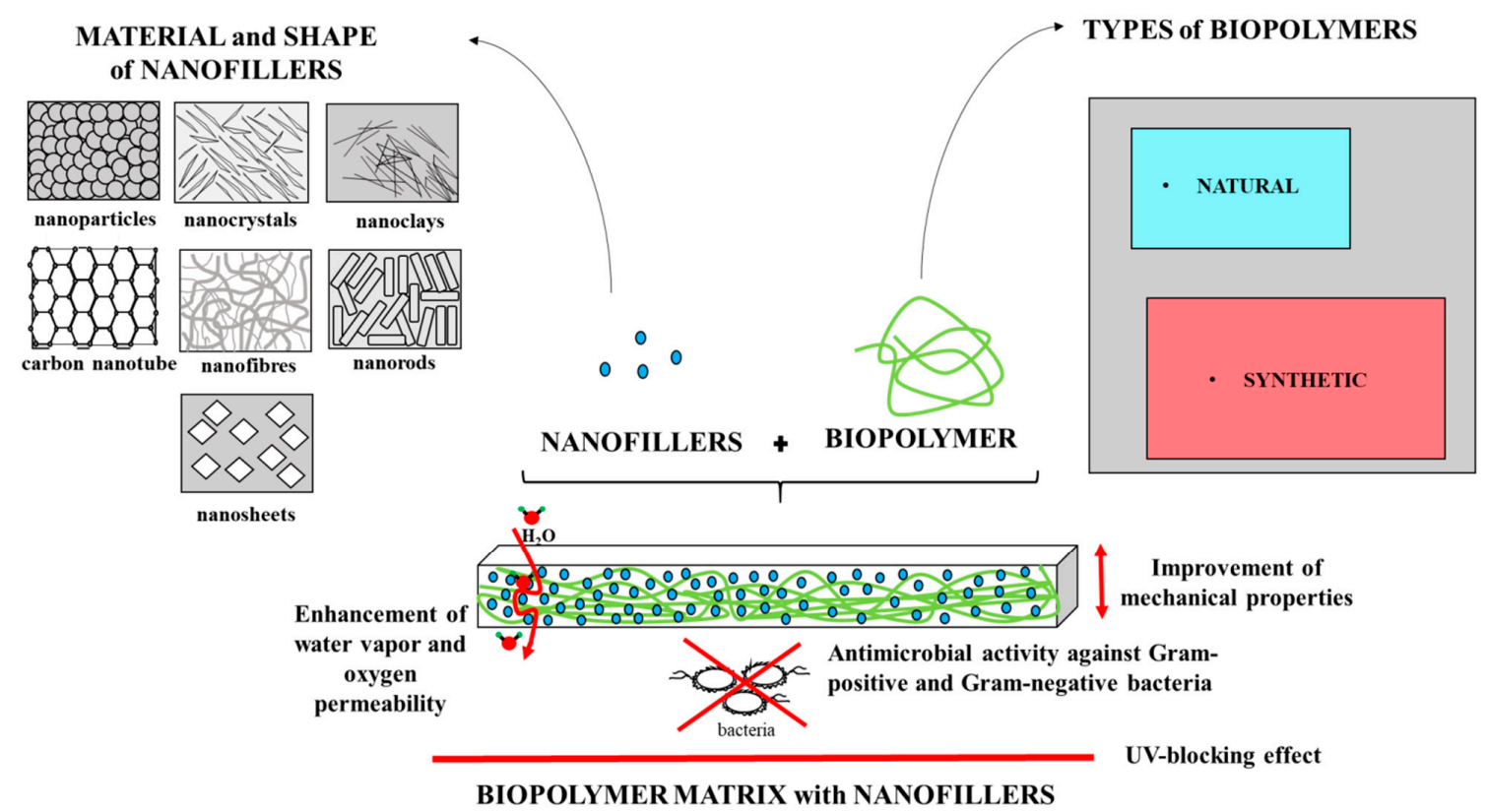

Figure 1. Schematic preparation of nanocomposite films and their functional properties.

The empty spaces in the structural network of nanocomposites can be occupied by water molecules. This phenomenon is considered the water content of the film $[87,141]$. The addition of nanofillers into the films can cause a decrease in water content. This behavior could be related to the interaction between nanofillers and functional groups of the biopolymer chain, which can lead to a reduction in the available spaces in the biopolymer matrix [87]. Noshirvani and co-workers (2018) developed starch-PVA films with cellulose nanocrystals (CNC). They noticed that the addition of the nanofiller caused a decrease in the moisture content of the film. Such behavior was demonstrated by the crystal structure of the $\mathrm{CNC}$, which causes lower water uptake than the polymer matrix and the formation of strong hydrogen interactions between the $\mathrm{CNC}$ and the starch-PVA matrix [138]. The addition of nano- $\mathrm{SiO}_{2}$ into whey protein isolate-pullulan matrix decreased moisture content of nanocomposite films. The strong interactions between components caused the diffusion of water molecules to nanocomposites [142].

An important property of biopolymer films, and in particular polysaccharide films, is the swelling degree, which determines the amount of absorbed water. As the value of the swelling degree increases, the tolerance of film to water increases [143]. In general, the addition of nanofillers improves the swelling degree and increases the water resistance of the films. This is attributed to the strong hydrogen interactions between the nanofiller/nanofiller and the nanofillers/biopolymer matrix [143]. However, the reverse trend can also be noticed. The addition of chitin nanofiber (CHNF) caused an incremental swelling degree of chitosan films, which was due to increased amount of $\mathrm{OH}^{-}$groups from $\mathrm{CHNF}$ and resulted in increased water absorption [144]. The same phenomenon was observed in the chitosan/starch films with halloysite nanotubes, which was attributed to the increased porosity and hydrophilicity of the nanocomposite films [145].

The water vapor permeability (WVP) is very important for fresh food products and for products where dehydration and absorption of moisture should be avoided. The values of WVP of packaging systems should be at the lowest possible level $[28,87,146]$. The water vapor permeability in biopolymer films is influenced by the chemical nature of macromolecules, porosity and crystallinity, degree of cross-linking, relative humidity, and addition of a plasticizer $[147,148]$. The addition of nanofillers to biopolymer films has an impact on the water vapor barrier properties. The low WVP of films is an important feature in the packaging of food products as they can reduce the moisture transfer between the inner and outer packaging environment [149]. The presence of impermeable nanoparticles in the biopolymer matrix prevents the mobility of the biopolymer chain, and consequently can lead to a reduction in the water vapor permeability of the nanocomposite films [28]. In addition, the hydrophobic 
character of nanoparticles (e.g., $\mathrm{TiO}_{2}$ ) affects the reduction of the WVP of the film, due to the low aspect ratio of this nanoparticle and the irregular strengthening of the chains [87]. Shankar et al. concluded that the presence of halloysite nanotubes and AgNPs creates an increased tortuous path for the passage of water vapor molecules through the alginate matrix. On the other hand, exceeding the critical concentration of nanofillers increases the water vapor permeability of nanocomposite films [150]. Similar patterns of changes in WVP properties have been observed in many studies [87,95,143,151-153].

The type of nanofiller used also has an effect on the WVP of films. Zahedi and co-authors (2018) established that sodium MMT nanoclay is more effective in the reduction of the WVP of carboxylmethyl cellulose films than ZnONPs. These differences may result from various structural and arrangement features. ZnONPs have a hexagonal close packaged structure, while MMT is a layered silicate structure [154]. Nanoclays impede the diffusion of the water vapor due to impermeable layers of this type of nanofiller $[155,156]$. However, the addition of another type of nanoclay, laponite-synthetic hectorite-like clay-to kafirin film, does not significantly affect the WVP of the tested films. The hydrophilic clay, due to the presence of Si-OH groups, can affect the hydrophilicity of the surface [157]. The same trend was observed in collagen films with laponite [158].

In related literature, the opposite effect on the water barrier properties of biopolymer films is also reported. The addition of MMT/alkylammonium (hexa- and tetra-decyltrimethylammonium) and MMT/chitosan to cellulose acetate coatings increased the WVP value of the film [159]. Also the capping agent used in the preparation of the nanoparticles is critical for the WVP of the film. CMC was used as a capping agent in preparation of ZnO NPs. The nanoparticles caused an increase in the WVP of the gelatin films, which is attributed to the hydrophilic nature of CMC used as capping agent [160]. Silva and co-workers (2019) prepared new nanocomposites based on laponite and cellulose nanofibers. They concluded that the increase in WVP is related to the hydrophilic nature of laponite [161].

Oxygen permeability (OP) is one of the crucial parameters of films used in food packaging. Low OP values are preferred, because oxygen can cause deterioration in the quality of packed food products [162]. The addition of nanofillers into biopolymer films may cause a decrease in the OP values. Wu et al. (2019) stated that the AgNPs addition into nanocellulose films with grape seed extracts caused the improvement in barrier properties of the tested films. AgNPs filled the interspaces of matrix and hindered the transfer of $\mathrm{O}_{2}$ molecules through the film [163]. The presence of nanocellulose also causes the reduction of OP of the film, which can be attributed to the formation of a dense network structure of the film matrix [152]. A similar phenomenon was observed with the addition of halloysite nanoclay into potato starch films. The reduction in the permeability values may result from the fact that gases have an extended diffusion path [164].

\subsection{Effects of Nanofillers on the Mechanical Properties of Polymer-Based Films}

Two main parameters which are often used to determine the mechanical properties of biopolymer films are tensile strength (TS, $\mathrm{MPa}$ ), which is used to measure strength, and the percentage of elongation at break $(\mathrm{EAB}, \%)$ which is used to determine the elasticity of the film. These parameters must meet certain standards to maintain integrity during packaging [149]. The addition of nanoparticles to biopolymer films significantly affects their mechanical properties. This may be due to the fact that nanoparticles have a very large specific surface area that can affect interfacial strength and degree of dispersion. Even distribution of nanoparticles within the biopolymer matrix results in a specific transfer of stress through the shear mechanism from the biopolymer matrix to the nanoparticles and could result in effective load transfer and increased strength of the film [31,165].

The phenomenon of strengthening the tensile strength may also result from the interaction between the nanofiller and the biopolymer matrix, where hydrogen and covalent bonds between nanoparticles and, for example, hydroxyl groups of biopolymer are formed, which leads to the strengthening of molecular forces between nanoparticles and the biopolymer $[143,166]$.

Nanofillers can fill the free space between biopolymer chains, which increases the intermolecular attraction force, making the biopolymer matrix very dense and less permeable [143]. Improvement in TS 
of polymer films by addition of nanofillers has been observed in films from konjac glucomannan [167], fenugreek seed gum [168], alginate [95], chitosan [169], agar [150], starch [121,143], soy protein [152], whey protein [87], and CMC [170].

Reinforcement of biopolymer films with different nanofillers have been studied by others. In the presence of nanoclay in a gelatin matrix, the values of TS of gelatin films improved [171]. The same trend was observed in starch-polyvinyl alcohol films with cellulose nanocrystals (CNC) [138]. The authors observed improvement of mechanical properties of these films due to the stiffness of the $\mathrm{CNC}$ and the formation of hydrogen bonds between the $\mathrm{CNC}$ and the polymer matrix. Popescu and co-workers found that incorporating rigid molecules of CNC into starch-PVA films induces orientation of the polymeric molecules and favors the formation of $\mathrm{H}$-bonds between the polymeric chains [172]. Oun and Rhim (2016) isolated cellulose nanocrystals from rice, wheat, and barley straws. They concluded that properties of carboxymethyl cellulose (CMC) films varied depending on the type of cellulose nanocrystals. The addition of rice and barley straw into CMC film improved tensile strength parameters. However, the best results of WVP were achieved in CMC films with wheat straw [102]. Also, the combination of different nanofillers affects the mechanical properties of films. The binary films (PLA-AgNPs and PLA-CNC) showed lower values of mechanical properties than ternary films (PLA/AgNPs/CNC). The addition of AgNPs and CNC into PLA films improves their tensile strength and modulus values, which is due to synergistic effect between AgNPs and CNC [107].

The changes in elongation at break (EAB) exhibit the opposite trend than TS, when the nanofillers are added into the film polymer matrix. Since the addition of nanoparticles causes a decrease in the $\mathrm{EAB}$ value. Therefore, the addition of nanoparticles can increase the strength of the film but do not affect its flexibility [166]. A similar trend was observed in soy protein films with nanocellulose. The reinforcement may affect the limited movement of the polymer chain by reducing the free volume in the polymer matrix [152].

The critical concentration of nanofillers, above which the TS values of films decrease, should also be mentioned. Too high concentration of NPs causes the biopolymer matrix to be unable to evenly distribute the NPs, resulting in the reduction of strength [173]. The same problem can be observed with the addition of other types of nanofillers such as nanocrystals, which in too high concentration tend to grow together into larger crystals [105] or nanoclays which due to their poor dispersion and high surface energy can cause a decrease in the TS [168]. The decrease in TS at high nanofiller concentrations may also be related to crosslinking decrease in blend film and the damage to the polymer network layers due to the presence of large NP agglomerates [87].

When nanofillers are added to the films, they can cause lower resistance of a polymer matrix and its fracture. This can lead to the formation of micropores in the matrix, change of the crack growth of the path and transformation of the matrix shape. The formation of small clusters of nanoparticles increases the number of cracks and contributes to creating holes with a role in the energy loss and flexibility mechanism. The reduction of the polymer-nanoparticle interface surface may be due to the increase in the size of the nanoparticles. Thus, concentration at higher levels of nanoparticles leads to an optimal level of plasticity and reduced elasticity [87].

The increase in the TS value and the decrease in the EAB value may also be related to the moisture content of the tested biopolymer films. Water can act as a plasticizer in films and a decrease in plasticizer content reduces the elasticity of the film, which may lead to an increase in TS and Young modulus (YM) and a reduction in EAB [171,174].

Vicentini and co-workers (2018) studied the effect of modified carbon nanostructures (p-methoxyphenyl functionalized, carbon nanohorns, and reduced graphene oxide) in poly(L-lactic acid) composites. They concluded that the mechanical properties depended on the type of nanofiller used, and these differences can be attributed to the different size and shape of nanofillers [175].

The presence of graphene oxide in the cellulose carbamate matrix caused improvement in tensile strength of nanocomposite films. The roughness of the larger surface of graphene oxide sheets ensures better adhesion with cellulose carbamate, which could lead to stronger mechanical blocking [129]. 
A similar enhancement in TS was reported in chitosan/graphene oxide nanosheet films [176]. Son et al. (2015) compared mechanical properties of sodium carboxymethyl cellulose/reduced graphene oxide and sodium carboxymethyl cellulose/graphene oxide films. They concluded that reduced graphene oxide could interact more effectively with sodium carboxymethyl cellulose than graphene oxide because reduced graphene oxide reacts with sodium carboxymethyl cellulose through strong van der Waals interactions and hydrogen bonds due to the presence of oxygen-containing functional groups on the edge of the reduced graphene oxide sheet [177].

The type of biopolymer also affects the mechanical properties (modulus, strength, and toughness) of nanocomposite films. Achaby et al. (2018) studied the effect cellulose nanocrystals addition on the mechanical properties of alginate, chitosan, and $\mathrm{k}$-carrageenan films. The increase in mechanical strength of the alginate films with the addition of $\mathrm{CNC}$ was caused by strong hydrogen and ionic interactions between the free hydroxyl groups of the CNC and the hydroxyl and carboxyl groups of the alginate. The same trend was found in $\mathrm{k}$-carrageenan films with $\mathrm{CNC}$, which the authors explained as a homogeneous $\mathrm{CNC}$ dispersion in the carrageenan matrix due to hydrogen bonds, which creates interfacial interaction between the CNC and the k-carrageenan [178]. Moreover, Kassab and co-workers (2019) concluded that the increase in the mechanical properties of carrageenan films is related to the specific properties of $\mathrm{CNC}$ which was extracted from sugarcane bagasse. The authors explained that the morphology (needle shape), surface functionality, large aspect ratio, and high degree of crystallinity of CNC are responsible for improving the mechanical properties of the $\mathrm{k}$-carrageenan film [179].

Different conclusions were observed in chitosan nanocomposite films. The addition of up to $5 \mathrm{wt} \%$ of $\mathrm{CNC}$ caused an increase of mechanical properties parameters, which can be attributed to the interaction between the anionic sulphate groups of the $\mathrm{CNC}$ and the cationic amide groups of the chitosan. In addition, the nano-reinforcing effect of $\mathrm{CNC}$ was achieved through effective stress transfer of the CNC-chitosan interface. The addition of CNC at the highest level $(8 \mathrm{wt} \%)$ caused a decrease in mechanical strength, which was related to the agglomeration phenomenon of $\mathrm{CNC}$ in the chitosan matrix. The addition of $\mathrm{CNC}$ also affects the elongation at break. The reduction of the EAB of each type of film is due to the rigid behavior of the CNC and its interactions with biopolymers that lead to a reduction in macromolecular biopolymer chains [178]. Kanmani and Rhim obtained three types of nanocomposite films based on agar, carrageenan, and CMC with ZnONPs. The addition of ZnONPs to the biopolymer films resulted in a decrease in TS and YM. In contrast, ZnONPs addition significantly increased the EAB of biopolymer films. The presence of ZnONPs did not interrupt the movement of polymer chains [180].

\subsection{Effects of Nanofillers on the Antimicrobial Activity of Polymer-Based Films}

The antimicrobial packaging system is intended to ensure the safety and prolong storage stability of food by preventing the development of microorganisms. The packaging materials can acquire antibacterial activity through:

(1) the addition of antibacterial substances to the biopolymer matrix;

(2) use of inherently antimicrobial polymer (for example polymer resins or chitosan);

(3) irradiation of a biopolymer matrix which results in the formation of reactive oxygen species (ROS) [181,182].

The antibacterial agents can be divided into two types: bactericidal, which kill bacteria; and bacteriostatic, which cause the inhibition of bacteria growth. The incorporation of nanoparticles into biopolymer films increased their antimicrobial activity. The mechanism of antimicrobial activity of nanoparticles depends on the type of nanoparticles as well as on the species and the natural properties of the bacteria. The bacteria's sensitivity to NPs is influenced by the bacterial cell wall structure and their growth rate. Fast-growing bacteria are more sensitive to NPs than slow-growing bacteria [87,183]. Moreover, the antibacterial activity of nanoparticles is greater in Gram-negative bacteria than in Gram-positive bacteria, which is due to the bacterial cell structure. Gram-positive 
bacteria have a thick three-dimensional layer of peptidoglycan $(\sim 20-80 \mathrm{~nm})$ that creates a specific barrier to nanoparticles and prevents them from entering inside the cell. A thin layer of peptidoglycan $(\sim 7-8 \mathrm{~nm})$ in Gram-positive bacteria is an ineffective barrier against released nanoparticles ions [184]. There are several hypotheses of the mechanism of antibacterial action of nanoparticles. The first of these concerns the interaction of negatively charged nanoparticles with biologically active molecules that are found on the surface of cells, which in turn can lead to the leakage of cellular components [85]. The second type of mechanism concerns the interactions of nanoparticles with bacterial DNA, resulting in cell death. The potential mechanisms of antimicrobial activities of nanofillers are illustrated by the example of nanoparticles shown in Figure 2.

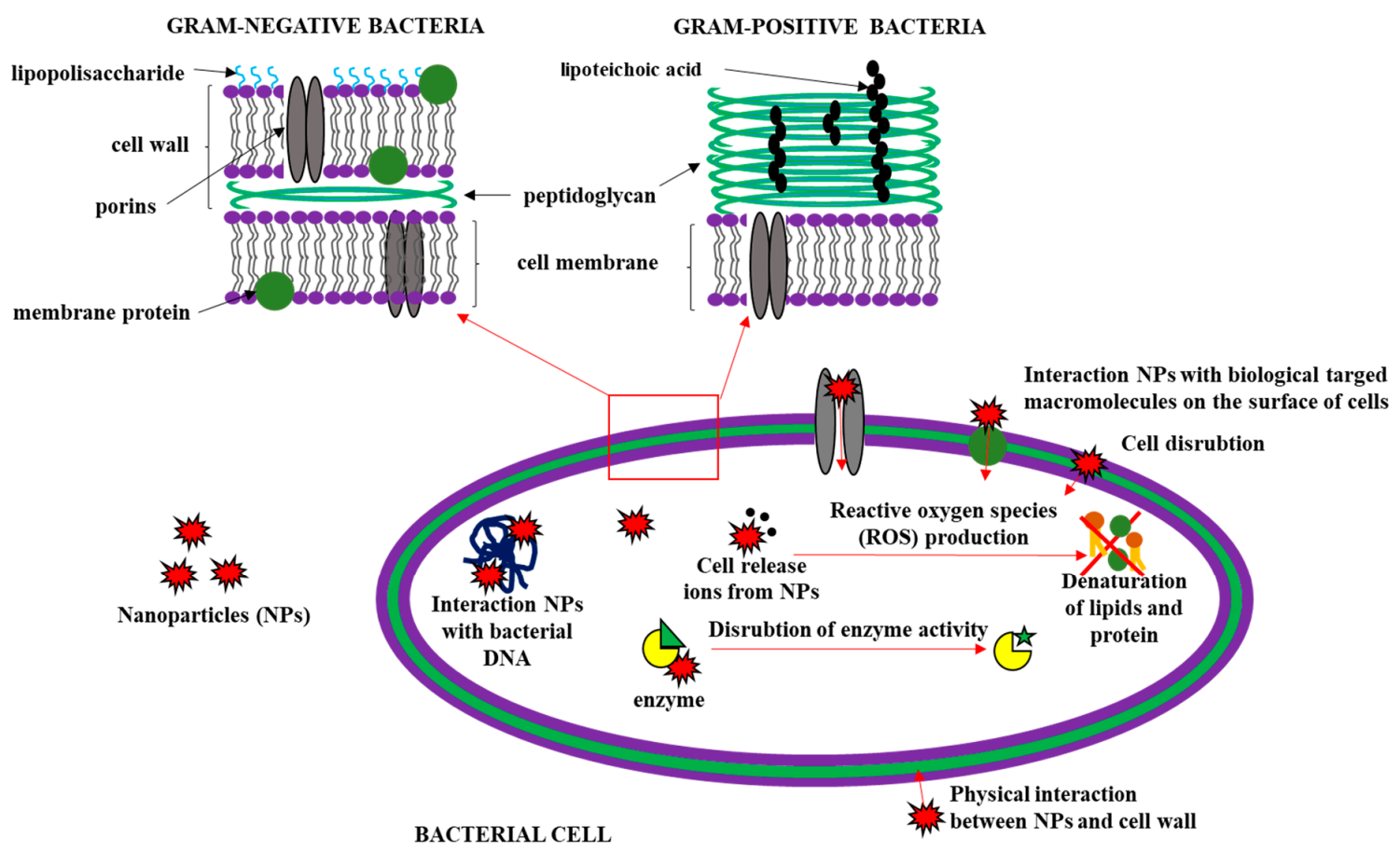

Figure 2. Potential mechanisms of antimicrobial activities of nanoparticles.

In addition, each type of nanoparticles could work differently. In the presence of $\mathrm{ZnONPs}, \mathrm{H}_{2} \mathrm{O}_{2}$ is generated [185], whereas sulfur ions, which are generated from SNPs, cause the formation of toxic $\mathrm{H}_{2} \mathrm{~S}$, which interacts with the -SH group and generates stress ROS $[85,186]$. The type of nanoparticles also affects their bactericidal activity. Small-sized nanoparticles have a stronger bactericidal effect [187], while a positive surface charge of metallic nanoparticles results in easier interaction with a negative charge of bacterial surfaces [188].

In related literature, many antibacterial aspects of nanostructures have been reported. The influence of various types of nanoclays (Cloisite $\mathrm{Na}+$, Cloisite 20A and Cloisite 30B) on the antibacterial properties of whey protein isolate (WPI) films was investigated. Only the presence of Cloisite 30B showed a bacteriostatic effect on L. monocytogenes, while none of the different types of nanoclays had any antibacterial effect against E. coli [189]. The antibacterial effect of Cloisite 30B can be attributed to the presence of a quaternary ammonium group in the silicate layer, which destroys bacterial cell membranes and causes cell lysis. The same behavior was observed in PLA films with Cloisite 30B [190]. Although hydrophilic NaMMT or organically modified montmorillonite (OrgMMT) do not show any particular antibacterial action, it has been shown that their addition to the film enhances the antibacterial effect of chitosan-PVA films [191].

Chitin nanofibrils (CNF) could be characterized as bacteriostatic rather than as a bactericidal agent. The addition of CNF into carrageenan matrix improved antimicrobial activity of nanocomposite films. The proposed mechanism of CNF activity consists of blocking access to nutrients and oxygen, 
which causes the bacteria to flocculate [192]. Salari and coworkers (2018) developed active chitosan films with bacterial cellulose nanocrystals (BCNC) and silver nanoparticles AgNPs. The antibacterial and antifungal properties of this type of film were related to the presence of AgNPs, while BCNC and chitosan had no antibacterial or antifungal activity [184]. The mechanism of antibacterial behavior of $\mathrm{ZnO}$ nanorods could have a physical basis. Nanorods could act like needles that easily pass through the bacterial cell wall [185]. The same results were reported in sago starch films with ZnO nanorods [193].

The high antimicrobial activity of GO is due to the physical destruction of cell membranes due to exceptionally sharp edges of GO and chemical oxidation through generation of ROS. In comparison to other carbon nanomaterials, graphene oxide has low cost of production and causes mild cytotoxicity to mammalian cells in low doses [194,195].

Increased attention is being paid to hybrid materials that give new properties to nanocomposite materials. Hybridization of metal nanoparticles and polymer can improve the properties of individual components. The addition of the hybrid of ZnO NPs-chitosan to starch films resulted in an increase in antibacterial activity against E. coli and S. aureus, compared to starch films alone [196]. Moreover, when a hybrid of PVA/GO/starch AgNPs was used in PVA matrix, an increase in the antibacterial properties have been observed, which might be due to the synergistic effects of GO and AgNPs in PVA matrix [197]. The addition of GO and CNC stimulates the antibacterial activity of PLA film, resulting in greater activity than single nanofillers [198].

Table 3 presents some recent studies on the impact of nanofillers on functional properties of nanocomposite films. 
Table 3. Recent examples of nanocomposite films.

\begin{tabular}{|c|c|c|c|}
\hline Nanofiller & Polymer & The Effect of Nanofiller Addition & Reference \\
\hline \multicolumn{4}{|c|}{ Metal Nanostructures } \\
\hline AgNPs & gelatin & $\begin{array}{l}\text { - Improvement of antibacterial effect from } 0 \text { up to } 14 \mathrm{~mm} \text { of inhibition zone against S. typhimurium, } \\
\text { B. cereus, L. monocytogenes, E. coli, and S.aureus } \\
\text { - Reduction of TS and YM by up to } \sim 25 \% \text { and } \sim 36 \% \text {, respectively, depending on AgNPs concentration } \\
\bullet \text { No changes in EAB, WVP, MC, and WCA }\end{array}$ & [199] \\
\hline AgNPs & chitosan-gelatin & $\begin{array}{l}\bullet \text { Reduction of TS }(\sim 27 \%) \text { and improvement of EAB }(\sim 34 \%) \\
\text { - Increased the shelf-life of red grapes on which the film was applied }\end{array}$ & [200] \\
\hline AgNPs & chitosan & $\begin{array}{l}\text { - Improvement of antimicrobial activity against P. aeruginosa (to } \sim 28 \mathrm{~mm} \text { of inhibition zone), S. aureus } \\
\text { (to } \sim 37 \mathrm{~mm} \text { ), and MRSA (to } 24.73 \mathrm{~mm} \text { ), depending on AgNPs concentration }\end{array}$ & [201] \\
\hline AgNPs & chitosan/cellulose & $\begin{array}{l}\text { - Improvement of antimicrobial activities against S. aureus }(\sim 0.8 \mathrm{~mm} \text { of inhibition zone) and } \\
\text { E. coli }(\sim 1.2 \mathrm{~mm})\end{array}$ & [202] \\
\hline AgNPs & chitosan/PVA & $\begin{array}{l}\text { - Improvement of antioxidant activity by up to } \sim 33 \% \text { (DPPH radical scavenging activity), up to } \sim 37 \% \\
\text { (ferric reducing ability) and up to } \sim 31 \% \text { ( } \beta \text {-Carotene bleaching), depending on AgNPs concentration } \\
\qquad \text { Low toxicity } \\
\text { - Improvement of antimicrobial activity against S. areus ( increase by } \sim 1 \mathrm{~mm} \text { of inhibition zone), B. cereus } \\
\quad(\sim 8 \mathrm{~mm}), \text { M. luteus }(\sim 2 \mathrm{~mm}) \text {, S.enterica }(\sim 3 \mathrm{~mm}) \text {, E. coli }(\sim 3 \mathrm{~mm}) \text {, and P. aeruginosa }(\sim 2 \mathrm{~mm})\end{array}$ & [203] \\
\hline $\begin{array}{l}\text { AgNPs } \\
\text { AuNPs }\end{array}$ & chitosan & $\begin{array}{c}\text { - Improvement of antimicrobial activity } \\
\text { - AuNPs has better activity against A. niger than AgNPs (from } 0 \text { to } 25 \mathrm{~mm} \text { of inhibition zone) } \\
\text { - AgNPs has better activity against C. albicans than AuNPs ( from } 6 \text { to } 19 \mathrm{~mm} \text { of inhibition zone) } \\
\text { Po significant difference between antimicrobial activity of AuNPs and AgNPs against S. aureus and } \\
\text { P. aeruginosa }\end{array}$ & [204] \\
\hline $\begin{array}{l}\text { AgNPs } \\
\text { SeNPs }\end{array}$ & furcellaran & $\begin{array}{l}\text { - Enhancement of MC (with AgNPs } \sim 11.5 \% \text { and with SeNPs } \sim 14 \% \text { ), WS, EM (with AgNPs and with } \\
\text { SeNPs } \sim 10 \% \text { ), but reduction in SR (with AgNPs } 13 \% \text { and with SeNPs } \sim 20 \% \text { ) } \\
\qquad \text { AgNPs improved the UV-blocking effect } \\
\bullet \text { No changes in EAB } \\
\text { - SeNPs improved antimicrobial activity against E. coli (SeNPs from } 0 \text { up to } \sim 38 \text { mm of inhibition zone; } \\
\text { AgNPs from } 0 \text { to } \sim 10 \mathrm{~mm} \text { ), S. aureus (SeNPs from } 0 \text { up to } \sim 22 \mathrm{~mm} \text { ), and MRSA (SeNPs from } 0 \text { up } \\
\text { to } \sim 26 \mathrm{~mm} \text { ) }\end{array}$ & [81] \\
\hline
\end{tabular}


Table 3. Cont

\begin{tabular}{|c|c|c|c|}
\hline Nanofiller & Polymer & The Effect of Nanofiller Addition & Reference \\
\hline SNPs & chitosan & $\begin{array}{l}\bullet \text { Increment of TS (by up to } \sim 18 \% \text { ), EM (by up to } \sim 18 \% \text { ) and WCA (by up to } \sim 6 \% \text { ) } \\
\bullet \text { Reduction of EAB (by up to } \sim 39 \% \text { ), WVP (by up to 14\%) } \\
\bullet \text { Enhancement of thermal stability } \\
\text { - Antimicrobial activity against L. monocytogenes (complete destroy after } 12 \mathrm{~h} \text { ) and E. coli } \\
\text { (complete destroy after } 6 \mathrm{~h} \text { ) }\end{array}$ & {$[85]$} \\
\hline Lignin capped AgNPs & agar & $\begin{array}{l}\bullet \text { Enhancement of UV screening effect } \\
\bullet \text { Improvement of TS (by up to } \sim 23 \% \text { ) and YM (by up to } \sim 13 \% \text { ) } \\
\bullet \text { No changes in EAB } \\
\text { - Reduction of WVP (by up to } \sim 22 \% \text { ), WCA (by up to } \sim 9 \% \text { ), WS (by up to } \sim 16 \% \text { ), and SR (by up to } \sim 50 \% \text { ) } \\
\text { - Improvement of antimicrobial activity against E. coli (complete destroy after } 6 \text { h) and L. monocytogenes } \\
\text { (complete destroy after } 12 \mathrm{~h} \text { ) }\end{array}$ & [150] \\
\hline $\mathrm{Ag}-\mathrm{Cu}$ NPs & gelatin & $\begin{array}{l}\bullet \text { Strong UV screening effect } \\
\bullet \text { Improvement in TS (by up to } \sim 49 \% \text { ) but reduction in EAB (by up to } \sim 40 \% \text { ) } \\
\bullet \text { Strong antimicrobial activity against S. thyphimurium (from } 3.5 \text { to } 7 \text { log) and L. monocytogenes } \\
\text { (from } 0.5 \text { to } 3 \text { log) } \\
\bullet \text { Enhancement of thermal stability }\end{array}$ & [173] \\
\hline $\begin{array}{l}\text { AgNPs inside } \\
\text { gelatin-montmorillonite } \\
\text { (AgM) }\end{array}$ & cellulose acetate & $\begin{array}{r}\text { - Improvement of UV barrier, TS (by up to } \sim 6 \% \text { ) and EM (by up to } \sim 18 \% \text { ), but reduction in EAB } \\
\text { (by up to } \sim 50 \% \text { ) } \\
\text { - Reduction of OP (by up to } \sim 14 \% \text { ) } \\
\bullet \text { Enhancement of thermal stability } \\
\text { - Improvement of antimicrobial activity against E. coli (from } 0 \text { to } 36 \mathrm{~mm} \text { of inhibition zone), S. aureus } \\
\text { (from } 0 \text { to } 34 \mathrm{~mm} \text { ), Salmonella (from } 0 \text { to } 32 \mathrm{~mm} \text { ), Psuedomonas (from } 0 \text { to } 35 \mathrm{~mm} \text { ), A. niger, and A. flavus, } \\
\text { depending on the AgNPs and thymol concentration }\end{array}$ & [205] \\
\hline $\begin{array}{c}\text { AgNPs } \\
\text { chitin nanofiber }\end{array}$ & chitosan & $\begin{array}{l}\text { - AgNPs reduced TS, YM, and color properties } \\
\text { - CHNF improved WS, SR, WVP, TS, and YM }\end{array}$ & [144] \\
\hline $\begin{array}{l}\text { AgNPs } \\
\text { nanocellulose }\end{array}$ & PVA & $\begin{array}{l}\bullet \text { AgNPs enhanced TS and EAB and reduced WVP } \\
\bullet \text { Enhancement of thermal stability } \\
\text { - Improvement of antimicrobial activity against E.coli and MRSA }\end{array}$ & [206] \\
\hline \multicolumn{4}{|c|}{ Metal Oxide Nanostructures } \\
\hline $\begin{array}{c}\text { Magnetite } \\
\text { nanoparticles }\end{array}$ & gelatin & - Enhancement of thermal stability & [207] \\
\hline
\end{tabular}


Table 3. Cont

\begin{tabular}{|c|c|c|c|}
\hline Nanofiller & Polymer & The Effect of Nanofiller Addition & Reference \\
\hline $\begin{array}{c}\text { Magnetic } \\
\text { nanoparticles }\end{array}$ & chitosan & - Improvement of TS (by up to $\sim 37 \%$ ) and EAB (by up to $\sim 18 \%$ ) & [208] \\
\hline $\mathrm{TiO}_{2} \mathrm{NPs}$ & gelatin & $\begin{array}{c}\bullet \text { Enhancement of TS (by up to } \sim 60 \% \text { ) and EAB (by up to } \sim 48 \% \text { ) } \\
\bullet \text { Improvement of barrier properties against UVC light } \\
\text { - Irradiation of the film with UV-A light }(365 \mathrm{~nm} \text { ) resulted in the most effective antibacterial activity } \\
\text { against E. coli }\end{array}$ & [209] \\
\hline $\mathrm{TiO}_{2} \mathrm{NPs}$ & gelatin-agar & $\begin{array}{c}\text { - Improvement of TS (by up to } \sim 29 \% \text { ) and reduction in EAB (by up to } \sim 22 \% \text { ) } \\
\bullet \text { Increment of WS (by up to } \sim 4 \% \text { ) and MC (by up to } \sim 10 \% \text { ) } \\
\bullet \text { Reduction of WVP (by up to } \sim 32 \% \text { ) } \\
\bullet \text { UV blocking effect }\end{array}$ & [146] \\
\hline $\mathrm{TiO}_{2} \mathrm{NPs}$ & chitosan & $\begin{array}{r}- \text { Improvement of antimicrobial activity against bacteria (S. aureus, E. coli, S. typhimurium, and } \\
\text { P. aeruginosa) and fungi (Aspergillus spp. and Penicillium spp.) } \\
\bullet \text { Enhancement of TS (by up to } \sim 56 \% \text { ), WVP (by up to } \sim 22 \% \text { ) and ethylene photocatalytic degradation } \\
\text { properties } \\
\bullet \text { Reduction of EAB (by up to } \sim 10 \%)\end{array}$ & [210] \\
\hline $\mathrm{TiO}_{2} \mathrm{NPs}$ & potato starch & $\begin{array}{l}\text { - Reduction of WS (by up to } \sim 9 \% \text { ), MC (by up to } \sim 11 \% \text { ) and WVP (by up to } \sim 35 \% \text { ) } \\
\text { - Improvement of TS (by up to } \sim 45 \% \text { ) and reduction of EAB (by up to } \sim 28 \% \text { ) } \\
\text { • Improvement of UV-blocking effect }\end{array}$ & [121] \\
\hline $\mathrm{CuONPs}$ & PVA-gelatin & - Improvement of UV screening effect & [123] \\
\hline ZnO NPs & gelatin & $\begin{array}{l}\text { - Improvement of UV screening effect and thermal stability } \\
\text { - Reduction of EM (by up to } \sim 82 \% \text { ) and TS (by up to } \sim 72 \% \text { ) } \\
\text { - Increment of WVP (by up to 99\%), MC (by up to } \sim 29 \% \text { ), WCA (by up to } \sim 20 \% \text { ) } \\
\text { - Improvement of antimicrobial activity against E. coli (from } 9 \text { to } 5 \text { log) and L. monocytogenes } \\
\text { (from } 9 \text { to } 1 \text { log) }\end{array}$ & [160] \\
\hline ZnO NPs & chitosan/CMC & $\begin{array}{l}\bullet \text { Improvement of shelf life of white soft cheese on which the film was applied } \\
\text { - Improvement of antibacterial activity against bacteria S. aureus (from } 5 \text { to } 11 \mathrm{~mm} \text { of inhibition zone) } \\
\text { P. aeruginosa (from } 3 \text { to } 11 \mathrm{~mm} \text { ), E. coli (from } 3 \text { to } 9 \mathrm{~mm} \text { ), and fungi C. albicans (from } 3 \text { to } 15 \mathrm{~mm} \text { ) } \\
\bullet \text { Improvement of TS (by up to } \sim 85 \% \text { ) }\end{array}$ & [211] \\
\hline $\mathrm{ZnO} N P s$ & chitosan & $\begin{array}{c}\bullet \text { Improvement of TS but reduction of EAB } \\
\text { - Improvement of antimicrobial activity against } E \text {. coli }(3.4 \log \text { reduction after } 0.5 \mathrm{~h}) \text { and S. aureus } \\
(4 \mathrm{log} \text { reduction after } 0.5 \mathrm{~h}) \\
\bullet \text { Biocompatibility and nontoxicity }\end{array}$ & [212] \\
\hline
\end{tabular}


Table 3. Cont

\begin{tabular}{|c|c|c|c|}
\hline Nanofiller & Polymer & The Effect of Nanofiller Addition & Reference \\
\hline $\mathrm{ZnO} \mathrm{NPs}$ & $\begin{array}{c}\text { mahua oil-based } \\
\text { polyurethane/chitosan }\end{array}$ & $\begin{array}{l}\bullet \text { Improvement of TS (by up to } \sim 56 \% \text { ) but reduction of EAB (by up to } \sim 20 \% \text { ) } \\
\bullet \text { Reduction of OP (by up to } \sim 3 \% \text { ) and WVP (by up to } \sim 37 \%) \\
\text { - Improvement of antimicrobial activity against E. coli }(\sim 25 \mathrm{~mm}) \text { and S. aureus }(\sim 20 \mathrm{~mm}) \\
\bullet \text { UV-screening ability and biodegradation } \\
\bullet \text { Non-cytotoxic }\end{array}$ & [213] \\
\hline $\mathrm{ZnO} \mathrm{NPs}$ & PLA & $\begin{array}{c}\bullet \text { Improvement of TS (by up to } \sim 37 \% \text { ), WVP (by up to } \sim 31 \% \text { ) and UV-light barrier properties } \\
\bullet \text { Reduction of EAB (by up to } \sim 10 \% \text { ) } \\
\text { - Improvement of antibacterial activity against E. coli (from } 10 \text { to } 3.5 \log \text { after } 12 \mathrm{~h} \text { ) and L. monocytogenes } \\
\text { (from } 12 \text { to } 8 \log \text { after } 12 \mathrm{~h} \text { ) }\end{array}$ & [31] \\
\hline $\mathrm{ZnO} \mathrm{NPs}$ & chitosan/PVA & - Improvement in photoluminescent properties and thermal stability & [214] \\
\hline $\mathrm{SnO}_{2} \mathrm{NPs}$ & $\mathrm{CMC}$ & $\begin{array}{l}\text { - The choice of nanocomposite preparation procedure caused four different morphologies of } \mathrm{SnO}_{2} \mathrm{NPs} \\
\text { (microcube, nanosphere, olive-like and nano-flower) which had different effects on thermal } \\
\text { stability of CMC }\end{array}$ & [125] \\
\hline $\begin{array}{l}\mathrm{ZnO} N P s \\
\mathrm{CuONPs}\end{array}$ & carrageenan & $\begin{array}{l}\text { - ZnONPs strongly improved antimicrobial activity against E. coli and L. monocytogenes, UV-blocking } \\
\text { effect and thermal stability } \\
\text { - Reduction of TS (by up to } \sim 55 \% \text { ) and EM (by up to } \sim 26 \% \text { ) depending on the CuO NPs and ZnO NPs } \\
\text { concentration and the ratio of nanoparticles } \\
\bullet \text { Improvement of EAB }\end{array}$ & [215] \\
\hline $\mathrm{Fe}_{2} \mathrm{O}_{3} \mathrm{NPs}$ & cellulose & - Improvement of TS (by up to $\sim 10 \%$ ) and YM (by up to $\sim 15 \%$ ) and thermal stability & [216] \\
\hline $\mathrm{MgO}$ NPs & $\begin{array}{l}\text { PLA/polyethylene } \\
\text { glycol }\end{array}$ & $\begin{array}{c}\text { - Improvement of EAB (by up to } \sim 86 \% \text { ) but reduction of TS (by up to } \sim 64 \% \text { ) } \\
\bullet \text { Enhancement of optical properties }\end{array}$ & [217] \\
\hline $\begin{array}{c}\alpha-\mathrm{Fe}_{2} \mathrm{O}_{3} \mathrm{NPs} \\
\text { FeNPs }\end{array}$ & chitosan/PVA & $\begin{array}{l}\text { - Improvement of magnetic properties } \\
\text { - FeNPs decreased TS and EM depending on the composition of chitosan and PVA } \\
\text { - } \mathrm{Fe}_{2} \mathrm{O}_{3} \text { NPs increased TS and EM depending on the composition of chitosan and PVA } \\
\text { - FeNPs and } \mathrm{Fe}_{2} \mathrm{O}_{3} \text { NPs caused reduction in EAB }\end{array}$ & [33] \\
\hline $\begin{array}{l}\text { ZnO nanorod } \\
\text { nano-kaolin }\end{array}$ & semolina & $\begin{array}{l}\text { - Reduction of OP (by up to } \sim 34 \% \text { ), MC (by up to } \sim 64 \% \text { ) and WS (by up to } \sim 56 \% \text { ), depending on the ratio } \\
\text { ZnO nanorods/nano-koalin } \\
\text { - Improvement of UV barrier properties and antimicrobial activity against } E \text {. coli (from } 0 \text { to } \sim 3 \mathrm{~mm} \text { ) }\end{array}$ & [218] \\
\hline $\mathrm{ZnO}$ nanorods & starch/gelatin & $\begin{array}{l}\bullet \text { Reduction of OP (by up to } \sim 61 \% \text { ) } \\
\text { - Improvement of TS (by up to } \sim 30 \% \text { ) but decrement of EAB (by up to } \sim 44 \% \text { ) } \\
\text { • Enhancement of UV barrier properties }\end{array}$ & [174] \\
\hline
\end{tabular}


Table 3. Cont

\begin{tabular}{|c|c|c|c|}
\hline Nanofiller & Polymer & The Effect of Nanofiller Addition & Reference \\
\hline $\mathrm{ZnO}$ nanorods & $\begin{array}{c}\text { gelatin/clove essential } \\
\text { oil }\end{array}$ & $\begin{array}{c}\text { - Reduction of TS (by up to } \sim 61 \% \text { ) and increment of EAB (by up to } 155 \% \text { ) and OP (by up to } 98 \% \text { ) } \\
\text { - Increment of oxygen and UV barrier property } \\
\text { - Improvement of antimicrobial activity against L. monocytogenes (from } 10 \text { to } 0 \text { log after } 7 \text { days) and } \\
\text { S. typhimurium (from } 10 \text { to } 0 \text { log after } 7 \text { days) } \\
\text { - Improvement of shelf-life of peeled shrimps }\end{array}$ & [219] \\
\hline $\mathrm{ZnO}$ nanorods & gelatin & $\begin{array}{c}\bullet \text { Decrement of hydrophobicity and moisture contents } \\
\bullet \text { Reduction of WVP (by up to } \sim 80 \% \text { ) } \\
\text { - Improvement of UV-blocking effect and antimicrobial activity against S. aureus (from } 0 \text { to } 80 \mathrm{~mm}^{2} \text { of } \\
\text { inhibition zone) }\end{array}$ & [185] \\
\hline $\mathrm{ZnO}$ nanorods & soybean polysaccharide & $\begin{array}{l}- \text { Reduction of WVP (by up to } \sim 36 \% \text { ) and OP (by up to } \sim 43 \% \text { ) } \\
\text { - Decrement of TS (by up to } \sim 18 \% \text { ) and increment of EAB (by up to } \sim 41 \% \text { ) and heat seal strength } \\
\text { (by up to } \sim 29 \% \text { ) } \\
\text { - Improvement of antimicrobial activity against } E \text {. coli (from } 7 \text { to } 5 \text { log after } 12 \mathrm{~h} \text { ) and S. aureus } \\
\text { (from } 6 \text { to } 1 \text { log after } 12 \mathrm{~h} \text { ) and UV-blocking effect }\end{array}$ & [220] \\
\hline $\mathrm{ZnO}$ nanorods & $\mathrm{PVA} / \mathrm{CMC}$ & - Improvement of dielectric properties & [221] \\
\hline \multicolumn{4}{|c|}{ Cellulose Nanostructures } \\
\hline cellulose nanocrystals & carrageenan & $\begin{array}{l}\text { - Improvement of TS (by up to } \sim 70 \% \text { ) and toughness (by up to } \sim 10 \% \text { ) parameters } \\
\text { - Reduction of EAB (by up to } \sim 25 \% \text { ) } \\
\text { - Enhancement of thermal stability }\end{array}$ & [179] \\
\hline $\begin{array}{l}\text { rice cellulose } \\
\text { nanocrystals }\end{array}$ & chitosan/PVA & $\begin{array}{c}\bullet \text { Improvement of TS (by up to } \sim 75 \% \text { ) and EM (by up to } \sim 98 \% \text { ) } \\
\bullet \text { Reduction of EAB (by up to } \sim 43 \% \text { ) } \\
\bullet \text { Enhancement of thermal stability } \\
\text { - No changes in antifungal against C. gloeosporioides and L. theobromae and antimicrobial against S. mutans, } \\
\text { S. aureus, E. coli, and P. aeruginosa activities }\end{array}$ & [222] \\
\hline cellulose nanocrystals & chitosan & - Improvement of mechanical properties (by up to $\sim 44 \%$ ) and thermal stability & [106] \\
\hline $\begin{array}{l}\text { flax cellulose } \\
\text { nanocrystals }\end{array}$ & chitosan & $\begin{array}{l}\bullet \text { Improvement of TS (by up to } \sim 24 \% \text { ), EAB (by up to } \sim 22 \% \text { ) and YM (by up to } \sim 140 \% \text { ) } \\
\bullet \text { Reduction of WVTR (by up to } \sim 11 \% \text { ) and increment of WVP (by up to } \sim 85 \% \text { ) } \\
\text { - Enhancement of antimicrobial activity against P. aeruginosa, E. faecalis, L. monocytogenes, E. coli, and } \\
\text { S. aureus (from } 6.31 \text { to } 16.05 \mathrm{~mm} \text { of inhibition zone) }\end{array}$ & [223] \\
\hline $\begin{array}{l}\text { bacterial cellulose } \\
\text { nanocrystal }\end{array}$ & PVA & $\begin{array}{c}\text { - Improvement of TS, YM, and toughness depending on the presence of glycerol, boric acid, and BCNC } \\
\text { - No changes in EAB }\end{array}$ & [105] \\
\hline
\end{tabular}


Table 3. Cont.

\begin{tabular}{|c|c|c|c|}
\hline Nanofiller & Polymer & The Effect of Nanofiller Addition & Reference \\
\hline $\begin{array}{c}\text { cellulose } \\
\text { nanowhiskers }\end{array}$ & chitosan & $\begin{array}{l}\text { - Increment of YM but reduction of TS and EAB } \\
\text { • Enhancement of thermal stability }\end{array}$ & [224] \\
\hline $\begin{array}{l}\text { nanocrystalline } \\
\text { cellulose }\end{array}$ & chitosan/guar gum & $\begin{array}{l}\text { - Improvement of the shear viscosity of the suspensions } \\
\text { - Reduction of air permeability (by up to } \sim 53 \% \text { ) and EAB (by up to } \sim 53 \% \text { ) } \\
\text { - Improvement of YM (by up to } \sim 86 \% \text { ) and TS (by up to } \sim 75 \% \text { ) }\end{array}$ & [225] \\
\hline $\begin{array}{l}\text { sugar palm } \\
\text { nanocrystalline } \\
\text { cellulose }\end{array}$ & sugar palm fibre & $\begin{array}{l}\text { - Reduction of MC (by up to } \sim 19 \% \text { ), WS (by up to } \sim 56 \% \text { ) } \\
\text { - Improvement of WVP (by up to } \sim 18 \% \text { ) and thermal stability }\end{array}$ & [153] \\
\hline $\begin{array}{l}\text { bacterial cellulose } \\
\text { nanocrystals and } \\
\text { AgNPs }\end{array}$ & chitosan & $\begin{array}{l}\bullet \text { Improvement of UV barrier properties } \\
\text { - Enhancement of physical, mechanical properties and in thermal stability, depending on the } \\
\text { concentration and ratio of AgNPs and BCNC } \\
\text { - Improvement of antimicrobial and antifungal activity (from } 0 \text { to } 96 \mathrm{~mm}^{2} \text { of inhibition zone depending } \\
\text { on the concentration and ratio of AgNPs and BCNC) }\end{array}$ & [184] \\
\hline cellulose nanocrystals & $\begin{array}{l}\text { chitosan } \\
\text { alginate } \\
\text { K-carrageenan }\end{array}$ & $\begin{array}{l}\text { - Improvement of YM, TS, and toughness in every type of film } \\
\qquad \text { Reduction in parameter of EAB }\end{array}$ & [178] \\
\hline $\begin{array}{l}\text { cotton linter cellulose } \\
\text { nanofibril }\end{array}$ & $\mathrm{CMC}$ & $\begin{array}{c}\text { - Improvement of TS (by up to } \sim 23 \% \text { ) and EM (by up to } \sim 28 \% \text { ) but reduction of EAB (by up to } \sim 26 \% \text { ) } \\
\bullet \text { Enhancement of thermal stability } \\
\bullet \text { Reduction of WCA (by up to } \sim 39 \% \text { ) } \\
\bullet \text { No changes in WVP }\end{array}$ & [226] \\
\hline celullose nanocrystals & CMC & $\begin{array}{l}\bullet \text { Enhancement of thermal stability } \\
\text { - Improvement of TS (by up to } \sim 74 \% \text { ) and EM (by up to } \sim 129 \% \text { ) and reduction of EAB (by up to } \sim 47 \% \text { ) }\end{array}$ & [227] \\
\hline cellulose nanofibers & soy protein & $\begin{array}{l}\text { - Improvement of TS (by up to } \sim 400 \% \text { ) and YM (by up to } \sim 767 \% \text { ) } \\
\bullet \text { Reduction of EAB (by up to } \sim 56 \% \text { ) } \\
\bullet \text { No effects of WVP }\end{array}$ & [228] \\
\hline cellulose nanocrystals & cassava starch & $\begin{array}{l}\text { - Reduction of WVP (by up to } \sim 43 \% \text { ), oil permeability (by up to } \sim 42 \% \text { ) and MC } \\
\bullet \text { Improvement of TS (5.6 times higher than cassava starch films) } \\
\bullet \text { Increment of WS }\end{array}$ & [229] \\
\hline cellulose nanocrystals & $\mathrm{PVA} / \mathrm{CMC}$ & $\begin{array}{c}\text { - Enhancement of TS (by up to } \sim 83 \% \text { ) and EM (by up to } \sim 147 \% \text { ) } \\
\text { • Reduction of WVP (by up to } \sim 82 \% \text { ) }\end{array}$ & [2] \\
\hline
\end{tabular}


Table 3. Cont

\begin{tabular}{|c|c|c|c|}
\hline Nanofiller & Polymer & The Effect of Nanofiller Addition & Reference \\
\hline $\begin{array}{l}\text { crystalline } \\
\text { nanocellulose }\end{array}$ & CMC/chitosan & $\begin{array}{l}\bullet \text { Enhancement of barrier against grease and oil } \\
\text { - Improvement of TS (52\% higher than CMC/chitosan films), YM, and WVP (by up to } \sim 38 \% \text { ) } \\
\bullet \text { Reduction of strain at break }\end{array}$ & [230] \\
\hline $\begin{array}{l}\text { Cellulose nanofibers } \\
\mathrm{TiO}_{2} \mathrm{NPs}\end{array}$ & whey protein & $\begin{array}{l}\bullet \cdot \mathrm{TiO}_{2} \text { increased the water resistance } \\
\text { - } \mathrm{TiO}_{2} \text { and } \mathrm{CNF} \text { improve mechanical properties and the values depended on the concentration of } \\
\text { nanofillers } \\
\text { - } \mathrm{TiO}_{2} \text { enhances antimicrobial activity against L. monocytogenes and S. aureus and antioxidant properties }\end{array}$ & [87] \\
\hline $\begin{array}{l}\text { licorice residue } \\
\text { nanocellulose }\end{array}$ & soy protein isolate & $\begin{array}{c}\bullet \text { Improvement of TS but reduction of EAB } \\
\bullet \text { Reduction in WVP (by up to } \sim 27 \% \text { ) and OP (by up to } \sim 55 \% \text { ) } \\
\bullet \text { UV-blocking effect }\end{array}$ & [152] \\
\hline \multicolumn{4}{|c|}{ Nanoclays } \\
\hline betonine nanoclays & chitosan/PVA & $\begin{array}{c}\bullet \text { Reduction of WVP (by up to } \sim 69 \% \text { ) and TS (by up to } \sim 30 \% \text { ) } \\
\bullet \text { Improvement of thermal stability } \\
\text { - Enhancement of antibacterial properties against E. coli (efficiency } 48.50 \% \text { ), P. aeruginosa (efficiency } 40 \% \text { ), } \\
\text { S. aureus (efficiency } 8 \% \text { ) }\end{array}$ & [231] \\
\hline cloisite $\mathrm{Na}+$ nanoclays & agar & $\begin{array}{l}\bullet \text { Improvement of TS (by up to } \sim 31 \% \text { ) } \\
\bullet \text { Reduction in WVP (by up to } \sim 50 \% \text { ), WCA (by up to } \sim 10 \% \text { ), and WS (by up to } \sim 23 \% \text { ) }\end{array}$ & [155] \\
\hline halloysite nanotubes & chitosan/starch & $\begin{array}{l}\bullet \text { Reduction of WS } \\
\text { - Improvement of water absorption capacity, porosity, folding strength, and WVTR } \\
\text { - Improvement of impermeability to bacteria (the microbial penetration test) }\end{array}$ & [145] \\
\hline $\begin{array}{l}\text { hallosite nanotubes } \\
\text { with metal ions } \\
\quad(\mathrm{Ag}, \mathrm{Zn}, \mathrm{Cu})\end{array}$ & $\mathrm{CMC}$ & $\begin{array}{c}\bullet \text { Improvement of WVP and thermal stability } \\
\bullet \text { Enhancement of antimicrobial activity against L. monocytogenes and E. coli } \\
\text { - Improvement in TS and EM but reduction of EAB (all results were depending on the type of metal ions } \\
\text { in hallosite nanutubes) }\end{array}$ & [232] \\
\hline 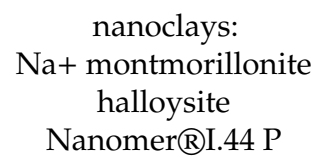 & fenugreek seed gum & $\begin{array}{l}\qquad \text { Enhancement of thermal stability } \\
\text { - No influence on antimicrobial activity against E. coli, S. aureus, B. cereus } \\
\text { - Antimicrobial activity against L. monocytogenes (all results were depending on the type of nanoclays) }\end{array}$ & [168] \\
\hline $\begin{array}{l}\text { halloysite nanotubes } \\
\text { loaded with the } \\
\text { essential oil }\end{array}$ & pectin & $\begin{array}{l}\text { - Reduction in thermal stability and EAB } \\
\text { - Improvement in TS and EM and surface hydrophobicity }\end{array}$ & [233] \\
\hline
\end{tabular}


Table 3. Cont

\begin{tabular}{|c|c|c|c|}
\hline Nanofiller & Polymer & The Effect of Nanofiller Addition & Reference \\
\hline $\begin{array}{l}\text { halloysite nanotubes } \\
\text { ZnO NPs }\end{array}$ & alginate & $\begin{array}{l}\bullet \text { Improvement of TS (by up to } \sim 12 \% \text { ), WVP (by up to } \sim 27 \% \text { ), and WCA (by up to } \sim 28 \% \text { ) } \\
\bullet \text { No changes in EAB (by up to } \sim 6 \% \text { ) and EM (by up to } \sim 7 \% \text { ) } \\
\text { - Improvement in UV-blocking effect and antimicrobial activity against } E \text {. coli (from } 7 \text { to } 0 \text { log after } 3 \mathrm{~h} \text { ) } \\
\text { and L. monocytogenes (from } 6 \text { to } 0 \text { after } 9 \mathrm{~h} \text { ) }\end{array}$ & [95] \\
\hline $\begin{array}{l}\text { Cloisite 30B } \\
\text { AgNPs }\end{array}$ & gelatin & $\begin{array}{c}\text { • Improvement of optical properties } \\
\text { - AgNPs improved TS while nanoclay increased EAB } \\
\text { - Enhancement of antimicrobial activity against E. coli and L. monocytogenes }\end{array}$ & [234] \\
\hline $\begin{array}{l}\text { bismuth tungstate/ } \\
\mathrm{TiO}_{2} \mathrm{NPs} \\
\left(\mathrm{Bi}_{2} \mathrm{WO}_{6}-\mathrm{TiO}_{2}\right)\end{array}$ & starch & $\begin{array}{c}\text { - Improvement of TS (by up to } \sim 233 \% \text { ) and photocatalytic activity } \\
\bullet \text { Reduction of EAB (by up to } \sim 15 \% \text { ) }\end{array}$ & {$[235]$} \\
\hline $\begin{array}{l}\text { halloysite } \\
\text { nisin }\end{array}$ & starch & $\begin{array}{c}\bullet \mathrm{HTN} \text { improved TS and YM } \\
\text { - Nisin reduced TS and YM but increased antimicrobial properties against L. monocytogenes, C. perfringens, } \\
\text { and S. aureus } \\
\bullet \text { No changes in WS }\end{array}$ & [236] \\
\hline $\begin{array}{l}\text { calcium } \\
\text { montmorillonite }\end{array}$ & carboxymethyl starch & $\begin{array}{r}- \text { Improvement of TS (by up to } \sim 500 \% \text { ), YM (by up to } \sim 1733 \% \text { ), and WCA (by up to } \sim 53 \% \text { ) } \\
\qquad \text { Reduction of EAB (by up to } \sim 49 \% \text { ), WS (by up to } \sim 4 \% \text { ) }\end{array}$ & [237] \\
\hline $\begin{array}{l}\text { montmorillonite } \\
\text { cellulose NPs }\end{array}$ & alginate & $\begin{array}{c}\bullet \text { Reduction of WVP } \\
\text { - } \mathrm{CNC} \text { increased the TS and EAB, while MMT in high concentration reduced the TS }\end{array}$ & [238] \\
\hline $\begin{array}{l}\text { montmorillonite - } \\
\text { CuO nanocomposites }\end{array}$ & chitosan & $\begin{array}{l}\bullet \text { Enhancement of TS, EAB, WVP, and OP } \\
\bullet \text { Reduction of WS and UV transition } \\
\text { - Improvement of antimicrobial activity against E. coli, P. aeruginosa, S. aureus, B. cereus (all results were } \\
\text { depending on the concentration and ratio of MMT and CuONPs }\end{array}$ & [169] \\
\hline $\begin{array}{l}\text { montmorillonite } \mathrm{ZnO} \\
\text { nanopowders }\end{array}$ & cationic starch & $\begin{array}{l}\text { - MMT reduced of WVP and UV light transmittance } \\
\text { - ZnO improved of WVP and UV light transmittance } \\
\text { - Improvement of TS and optical properties, but reduction of EAB }\end{array}$ & [166] \\
\hline $\begin{array}{l}\text { sodium } \\
\text { montmorillonite } \\
\text { nanoclay } \\
\mathrm{ZnO}\end{array}$ & $\mathrm{CMC}$ & $\begin{array}{c}\bullet \text { Reduction in WVP } \\
\text { - Addition of ZnO NPs increase UV-blocking effect } \\
\text { - Addition of ZnO NPs enhance antimicrobial activity against E. coli and S. aureus }\end{array}$ & [154] \\
\hline
\end{tabular}


Table 3. Cont

\begin{tabular}{|c|c|c|c|}
\hline Nanofiller & Polymer & The Effect of Nanofiller Addition & Reference \\
\hline \multicolumn{4}{|c|}{ Carbon Nanostructures } \\
\hline $\begin{array}{l}\text { multi-walled carbon } \\
\text { nanotube-Valine }\end{array}$ & chitosan/PVA & - Improvement of thermal stability & [239] \\
\hline $\begin{array}{l}\text { carbon nanotubes } \\
\text { AgNPs }\end{array}$ & chitosan & $\begin{array}{l}\text { - Enhancement of TS (by up to } \sim 131 \% \text { ), EAB (by up to } \sim 18 \% \text { ) and toughness (by up to } 125 \% \text { ) } \\
\text { • Reduction of dielectric properties }\end{array}$ & [240] \\
\hline graphene oxide & cellulose carbamate & $\begin{array}{l}\bullet \text { Improvement of thermal stability } \\
\text { - Improvement of TS (by up to } \sim 100 \% \text { ) and reduction of EAB (by up to } \sim 64 \% \text { ) }\end{array}$ & [129] \\
\hline $\begin{array}{c}\text { graphene } \\
\text { nanoplatelets }\end{array}$ & $\mathrm{CMC}$ & $\begin{array}{l}\text { - Reduction of ultimate tensile strength (by up to } \sim 50 \% \text { ) but increment of strain to break (by up to } \sim 66 \% \text { ) } \\
\qquad \text { Enhancement of UV-blocking effect } \\
\text { - Improvement of water repelling nature }\end{array}$ & [241] \\
\hline $\begin{array}{l}\text { reduced graphene } \\
\text { oxide }\end{array}$ & sodium CMC & - Improvement of TS (by up to $\sim 73 \%$ ) and YM (by up to $\sim 132 \%$ ) & [177] \\
\hline graphene oxide & amylose & $\begin{array}{l}\text { - Enhancement of stability in acidic and alkaline solutions } \\
\text { - Improvement of TS (16.5 times higher than amylose films) } \\
\text { • Reduction of the MC and UV transmittance }\end{array}$ & [242] \\
\hline $\begin{array}{l}\text { graphene oxide } \\
\text { reduced graphene } \\
\text { oxide }\end{array}$ & $\begin{array}{l}\text { sodium } \mathrm{CMC} / \text { silk } \\
\text { fibroin }\end{array}$ & - Improvement of thermal stability & [131] \\
\hline \multicolumn{4}{|c|}{ Other Nanostructures } \\
\hline melanin nanoparticles & carrageenan & $\begin{array}{c}\text { - Increment of TS (by up to } \sim 27 \% \text { ), EAB (by up to } \sim 25 \% \text { ), WVP (by up to } \sim 25 \% \text { ) and WCA (by up to } \sim 25 \% \text { ) } \\
\bullet \text { Reduction of YM (by up to } \sim 38 \% \text { ) } \\
\text { - Enhancement of antioxidant activity (by up to } \sim 962 \% \text {-DPPH method and by up to } \sim 559 \% \text {-ABTS method) } \\
\text { and thermal stability } \\
\bullet \text { Improvement of antimicrobial activity against L. monocytogenes and E. coli }\end{array}$ & [243] \\
\hline ZnS NPs & chitosan/PVA & $\begin{array}{l}\bullet \text { Reduction of WS and SR } \\
\text { - Improvement of TS and thermal stability and reduction of EAB (all results were correlating with the type } \\
\text { of plasticizer) }\end{array}$ & [244] \\
\hline $\begin{array}{l}\text { guar gum benzoate } \\
\text { NPs }\end{array}$ & gelatin & $\begin{array}{l}\text { - Improvement of antimicrobial activity against E. coli and S. aureus } \\
\text { • Enhancement of thermal stability } \\
\text { - Improvement of TS (by up to } 67 \% \text { ) and YM (by up to } \sim 550 \% \text { ) } \\
\text { - Reduction in EAB (by up to } \sim 63 \% \text { ) }\end{array}$ & [245] \\
\hline
\end{tabular}


Table 3. Cont

\begin{tabular}{|c|c|c|c|}
\hline Nanofiller & Polymer & The Effect of Nanofiller Addition & Reference \\
\hline chitosan NPs & $\begin{array}{l}\text { rice straw } \\
\text { nanofibrillated cellulose }\end{array}$ & $\begin{array}{l}\text { - Improvement of TS (by up to } \sim 40 \% \text { ) and YM (by up to } \sim 42 \% \text { ) but reduction of EAB (by up to } \sim 94 \% \text { ) } \\
\text { - Enhancement of antimicrobial activity against bacteria (S. aureus, E. coli), and yeast (S. cervisiae) } \\
\bullet \text { Reduction in porosity } \\
\bullet \text { No changes in WVP }\end{array}$ & [110] \\
\hline chitosan NPs & tara gum & $\begin{array}{c}\bullet \text { Improvement of TS and reduction of EAB } \\
\text { - Reduction of WS (by up to } 74 \% \text { ), WVP (by up to } \sim 23 \% \text { ) and MC (by up to } \sim 24 \% \text { ) } \\
\text { - Antimicrobial activity against E. coli (from } 0 \text { to } 87.32 \mathrm{~mm}^{2} \text { of inhibiton zone) and S. aureus (from } 0 \text { to } \\
111.71 \mathrm{~mm}^{2} \text { ) }\end{array}$ & [246] \\
\hline chitosan NPs & PVA/mulberry extract & - Improvement of TS but reduction of EAB & [111] \\
\hline lignin NPs & $\begin{array}{l}\text { chitosan } \\
\text { PVA } \\
\text { chitosan/PVA }\end{array}$ & $\begin{array}{l}\bullet \text { Improvement of TS and YM of PVA films } \\
\bullet \text { Enhancement of thermal stability of chitosan, PVA, and chitosan/PVA films } \\
\bullet \text { Improvement of UV barrier properties of tested films } \\
\bullet \text { Enhancement of antioxidant activity of chitosan films with LNP } \\
\text { - Improvement of antimicrobial activity against Erwinia carotovora subsp. carotovora and Xanthomonas } \\
\text { arboricola pv. Pruni }\end{array}$ & [247] \\
\hline $\begin{array}{l}\text { chitosan/gallic acid } \\
\text { NPs }\end{array}$ & konjac glucomannan & $\begin{array}{l}\bullet \text { Improvement of UV barrier properties } \\
\text { - Enhancement of TS (by up to } \sim 43 \% \text { ) but reduction of EAB (by up to } \sim 16 \% \text { ) and WVP (by up to } \sim 33 \% \text { ) } \\
\text { - Improvement of antimicrobial activity against S. aureus (from } 0 \text { to } 20 \mathrm{~mm} \text { of inhibition zone) and E. coli } \\
\text { (from } 0 \text { to } 12 \mathrm{~mm} \text { ) }\end{array}$ & [167] \\
\hline chitin nanofiber & gelatin/CMC & $\begin{array}{c}\bullet \text { Reduction of WS, SR and WVP } \\
\bullet \text { Improvement of TS }\end{array}$ & [109] \\
\hline chitin nanowhiskers & maize starch & $\begin{array}{l}\text { - Improvement of TS (by up to } \sim 125 \% \text { ) and thermal stability but reduction of EAB (by up to } \sim 37 \% \text { ) and } \\
\text { WVP (by up to } \sim 58 \% \text { ) } \\
\text { • Enhancement of antimicrobial activity against E. coli and L. monocytogenes }\end{array}$ & [143] \\
\hline $\begin{array}{l}\text { oxidized chitin } \\
\text { nanocrystals }\end{array}$ & CMC & $\begin{array}{l}\bullet \text { Improvement of TS (by up to } \sim 88 \% \text { ) and EM (by up to } \sim 244 \% \text { ) } \\
\text { - Reduction of WVP (by up to } \sim 10 \% \text { ), WCA (by up to } \sim 14 \% \text { ) and EAB (by up to } \sim 65 \% \text { ) }\end{array}$ & [248] \\
\hline $\begin{array}{l}\text { chitin nanowhiskers } \\
\text { /hybrid ZnO-Ag NPs }\end{array}$ & CMC & $\begin{array}{l}\bullet \text { Enhancement of thermal stability and UV-barrier property } \\
\text { - Improvement of TS (by up to } \sim 32 \% \text { ) and YM (by up to } 101 \% \text { ) but reduction of EAB (by up to } \sim 34 \% \text { ) } \\
\text { - Enhancement of antimicrobial activity against E.coli (from } 6 \text { to } 0 \text { log after } 6 \text { h) and L, monocytogenes } \\
\text { (from } 7 \text { to } 4 \text { log after } 9 \text { h) } \\
\text { - Reduction of WVP (by up to } \sim 23 \% \text { ) }\end{array}$ & [249] \\
\hline
\end{tabular}


Table 3. Cont

\begin{tabular}{|c|c|c|c|}
\hline Nanofiller & Polymer & The Effect of Nanofiller Addition & Reference \\
\hline pullulan & lysozyme nanofibers & $\begin{array}{l}\text { - Improvement of YM (by up to } \sim 48 \% \text { ), TS (by up to } \sim 7 \% \text { ) but reduction of EAB (by up to } \sim 80 \% \text { ) } \\
\text { - Enhancement of antioxidant activity (from } 0 \text { to } \sim 80 \% \text { DPPH method) and antimicrobial activity against } \\
\text { S. aureus }\end{array}$ & [250] \\
\hline chitosan & $\begin{array}{l}\text { nanocrystalline erbium } \\
\text { doped hydroxyapatite }\end{array}$ & - Improvement in antimicrobial activity against E. coli and S. aureus & [251] \\
\hline $\begin{array}{l}\text { potato starch } \\
\text { tapioca starch } \\
\text { chitosan }\end{array}$ & turmeric nanofiber & $\begin{array}{c}\qquad \text { Improvement of TS, YM, and thermal stability } \\
\bullet \text { Reduction of EAB } \\
\text { - Antimicrobial activity against B. cereus, E. coli, S. aureus, and S. typhimurium (the values were depending } \\
\text { in the type of biopolymer) }\end{array}$ & [252] \\
\hline maltodextrin & polyvinyl acetate NPs & - Improvement of TS (by up to $106 \%$ ) & [165] \\
\hline
\end{tabular}

Abbreviations: NPs—nanoparticles; CMC—carboxymethyl cellulose; PVA—poly(vinyl) alcohol; PLA—poly(lactic acid); TS—tensile strength; EAB—elongation at break; YM—Young's modulus; EM—elastic modulus; WVP—water vapor permeability; OP—oxygen permeability; WS—-water solubility; SR—swelling ratio; MC—-moisture content; WCA—-water contact angle. 


\section{Functional Application of Biopolymer-Based Films with Nanofillers}

Although many countries have made legal regulations regarding the contact of nanomaterials with food or with human skin, those regulations vary from country to country. Moreover, the definition of 'nanomaterial' is not even unified between countries. The detailed review of the legal status regulations for nanomaterials in EU has been recently performed by Rauscher et al. [253]. Nanomaterials that are allowed for use in contact with humans are required to have a detailed risk assessment [254]. This chapter is devoted to nanocomposite materials and their use in various areas of life.

\subsection{Food Preservation Application}

Packaging materials made from natural biopolymers are characterized by poor mechanical properties and high WVP parameters. The utilization of nanotechnology in this field may help to improve these parameters as well as give them completely new active properties. The main task of the nanocomposite packaging is to increase the shelf-life of food during storage and distribution [67].

Chitosan-gelatin films with the addition of AgNPs have been used to protect red grapes. Preliminary studies confirmed the active nature of such coatings, extending the storage time of grapes. The addition of $0.05 \%$ AgNPs in the chitosan-gelatin films resulted in the extension of the red grapes shelf-life with no signs of molds for 14 days, whereas the concentration of $0.1 \%$ AgNPs prolonged the shelf-life to 18 days [200]. In another case, AgNPs were incorporated into chitosan films and prolonged the storage time of litchi from 4 to 7 days [5]. The incorporation of MMT into starch-cashew tree gum increased protection against moisture loss of cashew nut kernels. However, the MMT additive did not achieve the critical value of peroxides for acceptance $\left(10\right.$ or $\left.20-30 \mathrm{mEq} \mathrm{O}_{2} \mathrm{~kg}^{-1}\right)$ [6].

Soft white cheese was packed into chitosan-PVA films with $\mathrm{TiO}_{2} \mathrm{NPs}$ and stored at $7{ }^{\circ} \mathrm{C}$ for 30 days. After 15 days of storage, the number of coliforms significantly decreased in the samples coated with films with $2 \%, 4 \%$, and $8 \% \mathrm{TiO}_{2}$ (by $1.47,1.47,1.30 \mathrm{log}$ cfu/g cheese, respectively, compared to the control $(1.90 \log \mathrm{cfu} / \mathrm{g})$. The results showed that bionanocomposite films with strong antimicrobial activity against gram positive (S. aureus), gram negative (P. aeruginosa, E. coli) bacteria and fungi (C. albicans) could be used as an environmentally friendly material for food packaging. Additionally, the lack of migration of $\mathrm{TiO}_{2}$ from the film to cheese was confirmed, which proves the high safety of this type of material [7]. Nanostructured chitosan-manolaurin films caused a reduction of L. monocytogenes population (by 2.3-2.4 log) on ultrafiltered cheese after 14 days [8].

The addition of $\mathrm{ZnO}$ nanoparticles into mahua oil-based polyurethane/chitosan film significantly influenced antibacterial properties when these films were used for packing carrot slices. After 9 days of storage, carrot slices packed in mahua oil-based polyurethane/chitosan+ ZnO NPs films had a lower degree of bacteria growth (by approx. 0.3-0.6 log cfu/g) than pieces of carrot slices without film and with PE film [213]. Antimicrobial activity against E. coli and L. monocytogenes was recorded for cooked minced fish paste packaged in PLA films with ZnO NPs and after 10 days of storage, the number of colonies of both bacteria was reduced to zero. The antimicrobial activity might have resulted from direct contact of microorganisms with $\mathrm{ZnO} N P s$ or $\mathrm{Zn}^{2+}$ ions emitted from the film [31]. The addition of ZnO NPs into chitosan/CMC also positive influenced packaged Egyptian white soft cheese (rheological properties, color measurements, moisture, $\mathrm{pH}$, and titratable acidity) during storage [211]. The starch-halloysite-nisin nanocomposite films effectively protected Minas Frescal cheese against post-process contamination with L. monocytogenes [236]. Echeverria and co-workers (2018) investigated the effect of MMT and clove essential oil in starch films on storage of muscle fillets of bluefin tuna (Thunnus thynnus). They noticed that the presence of clay prolonged the antimicrobial and antioxidant effects of clove essential oil, while no migration of clay's metal ( $\mathrm{Si}$ and $\mathrm{Al}$ ) into the muscle of the fish were observed [9]. Mathew and co-workers (2019) developed PVA/MMT K10 clay/AgNPs films and used them to improve the shelf-life of chicken sausages. The results showed that this type of nanocomposite packaging system is suitable for sausages, inhibiting the growth of total aerobic bacteria [10]. 
Starch/cellulose nanocrystal/grape pomade extract 'Viognier', nanocomposite films exhibited the highest antibacterial effect against $L$. monocytogenes inoculated on the ready-to-eat chicken meats during a 10-day storage period at $4{ }^{\circ} \mathrm{C}$ [11]. Strong antimicrobial properties were exhibited by chitosan-starch-cellulose nanofibrils films during storage of fresh beef sirloin [12]. The antimicrobial properties and high biocompatibility of chitosan/GO/TiO 2 NPs nanocomposite films were observed when used in packaging strawberries and mangos. The results indicated that nanocomposite wrap effectively delays loss of weight in fruits, with weight loss below $5 \%$ after 7 days of storage, and prevents bacterial contamination in food products [13].

The influence of nanofillers on the properties of LDPE synthetic film was also studied. The use of CuNPs as an active additive to LDPE films positively influenced the shelf-life of Peda (Indian sweet dairy product) [151]. Luo et al. (2015) incorporated nano-SiO ${ }_{2}$ into LDPE films and used this type of packaging for storing chilled white shrimps. $\mathrm{LDPE}+$ nano- $-\mathrm{SiO}_{2}$ are an active packaging material with antimicrobial and enzyme-inhibiting properties, in which shrimps remain fresh for 8 days [14]. Donglu and co-authors obtained a nanocomposite packaging material from LDPE and $\mathrm{SiO}_{2} / \mathrm{TiO}_{2} / \mathrm{Ag} \mathrm{NPs}$, which regulated $\mathrm{CO}_{2}$ and $\mathrm{O}_{2}$ levels as well as inhibited the growth of microorganisms and scavenge ethylene during storage of mushrooms (Flammulina velutipes) [15].

Sodium CMC nanocomposite films with photoluminescent ZnS NPs exhibited a blue emission centered at $445 \mathrm{~nm}$ under UV light excitation, which can be easily incorporated into paper sheets in order to prepare protective paper, which can be used as a food packaging [255]. Rice straw nanofibrillated cellulose (NFC)/CHNPs nanocomposite films were used to coat baggasse paper. The coating of paper sheets confirmed improvement in paper sheet properties, improving the tensile strength, grease-proof properties, antibacterial activity, and reduced porosity [110]. El-Wakil and co-workers used gluten/CNC/TiO 2 NPs nanocomposite films to coat paper sheets. The paper sheets coated with the aforementioned nanocomposite showed antimicrobial activity against $S$. cervisiae, E. coli, and S. aureus [256]. Nevertheless, further research is necessary to confirm the use of paper sheets coated with nanocomposite as an active packaging system, because there is still a lack of relevant in vivo studies.

In addition, the effectiveness of halloysite nanotubes as nanocontainers for active substances - sodium sorbate (a commonly used food preservative) - embedded in the zein matrix was tested. Preliminary studies have shown that it is possible to obtain an active packaging that has special packaging systems for the controlled release of active substances [257]. The presence of nanoclay in carnauba wax coatings enhanced the sensory acceptability and nutritional quality and effectively prevented the weight loss of 'Valencia' oranges (Citrus sinensis L. Osbeck) during storage at $4{ }^{\circ} \mathrm{C}$ for 8 weeks [258].

Currently, a large limitation in the commercial use of nanocomposite materials is the level of transition of nanomaterials from packaging to the food matrix. Although a number of studies have been carried out on the effects of using nanocomposites on prolonged storage of various types of food, consumers and legislation bodies expect confirmation of the safety of using nanocomposite packaging. One of the main concerns related to the use of nanocomposites is the emergence of new, diverse strains of bacteria and allergens, as well as the increased degree of adsorption of nanomaterials within the environment [67]. There are studies in which the migration of nanoparticles from food packaging has been studied $[259,260]$. Biodegradable starch/clay nanocomposite films could be used as food packaging owing to their low overall migration limit [260]. In addition, contact tests using food simulants are carried out to check the safety of the obtained nanocomposite materials. For example, the chitosan films with SeNPs met the required regulations and European directives on food packaging (EN1186-1, 2002), according to Commission Regulation No. 10/2011 [261].

\subsection{Wound Dressing}

The presence of ROS in wound often hampers wound healing. Cerium oxide nanoparticles $\left(\mathrm{CeO}_{2} \mathrm{NPs}\right)$ with strong antioxidant properties may contribute to active ROS purification. One of the 
methods for the production of wound dressings is the electrospinning technique, which consists in obtaining fibers ranging from tens of nanometers to micrometers [262]. Naseri-Nosor and co-workers (2017) developed $\mathrm{CeO}_{2}$ NPs with poly ( $\varepsilon$-caprolactone)/gelatin films as potential wound dressing material. After 2 weeks, wounds treated with PCL/gelatin $+1.5 \% \mathrm{CeO}_{2}$ exhibited complete wound closure compared to control film without $\mathrm{CeO}_{2}$ [263].

To prevent damage caused by the removal of wound dressings, plasma treated with electrospun polycaprolactone was coated with gelatin-silver nanoparticle membranes using the multi-immersion technique. Compared to monolayer coating, this type of multilayer coating (six-time coated membrane) accelerated the healing of wounds by 3 days. Moreover, the membrane did not adhere to the wound during peeling off, preventing damage to the newly formed tissue [264]. The antibacterial chitosan/poly(vinyl pyrrolidone)(PVP)/nanocellulose films exhibited good compatible property and low cytotoxicity with blood. Moreover, this type of nanocomposite films could be used as wound dressing material due to their swelling, thermal, and mechanical properties [71]. The reinforcement of nanostarch in chitosan/PVP/1\%-Stearic acid films caused the enhancement in the healing effect of albino rats [71].

Antimicrobial agent, chlorhexidine (CLX), was intercalated between the layers of MMT in the chitosan films. The chitosan films with MMT containing 5\% CLX were non cytotoxic, whereas in the case of $1 \%$ CLX films only film with neat CLX resulted in cytotoxicity. The localized and prolonged release of CLX on the chitosan-MMT matrix could be a good solution in the area of wound dressings [265]. Cacciotti and coworkers (2018) designed poly(lactic) acid fibrous membranes with addition of $\mathrm{H}_{2} \mathrm{~S}$ slow releasing donors extracted from garlic. The obtained antibacterial fibrous scaffolds/patches not only have the ability to stimulate cMSC (cardiac mesenchymal stem cells) proliferation, but also reduce oxidative damage [266].

Currently, nanotechnology is continuing to gain interest in the field of skin regeneration. On a laboratory scale, nanofillers placed in a polymer matrix accelerate wound healing, due to their antibacterial activity and improved angiogenesis. There are several important issues regarding the use of nanofillers in the wound healing process. Above all is the issue of dressing stability, so that nanofillers do not form a covalent bond with the polymer chain. In addition, there is still little data which would study the long-term safety of the use of nanofillers. Therefore, the mechanism of nanofillers should be thoroughly studied in order to be able to manage the cell behaviors. Understanding the mechanism of nanofillers will create a broader perspective on the safety of their use, which is why the long-term control over the performance of nanofillers is required [267].

\subsection{Drug and Enzyme Delivery System}

A drug delivery system is based on the delivery of a pharmaceutical drug to a specific site of a disease with minimized toxicological risk. Nanotechnology supports this by producing nano-scale materials, which can be successfully used as carriers [268]. A gelatin film with magnetic nanoparticles can be used as a control system for drug release, where the use of a magnetic field is important. Research has confirmed that without a magnetic field, this type of film acts as a blockage of drug release, while under the influence of a magnetic field, it opens the diffusion pathways [207]. Javanbakht and Namazi (2018) obtained flexible nanocomposite CMC hydrogel films with graphene quantum dots and anticancer drug, doxorubicin, release property. This type of nanocomposite caused $\mathrm{pH}$-sensitivity and consecutively prolonged the release of doxorubicin and showed non-significant toxicity against blood cancer cells (K562) [269].

Nanocomposite films not only can be carriers of drugs, but also for example, can transport proteolytic enzymes during the wine production process. Bromelain produced from pineapple stem is a proteolytic enzyme, which reduces the haze potential of white wines. Chitosan films with different nanoclays (MMT, sepiolite, and bentonite) were produced as supports for the covalent immobilization of proteolytic enzymes. The addition of these clays affected the amount of immobilized protein, which was higher for all the nanocomposite films compared to the clay-free sample (with the exception of 
modified bentonite). On the other hand, the addition of nanoclays negatively affected the catalytic properties of the immobilized protease [270].

\subsection{Tissue Engineering Application}

Tissue engineering relies on the regeneration of damaged tissues or organ reconstruction. One of the methods used in tissue engineering is the use of materials that act as implantable scaffolds. Nanotechnology proposes to create nanocomposites that offer different structures and properties [271].

Hassan and co-workers (2018) obtained nanocomposite scaffolds based on chitosan and CMC AgNPs decorated on carboxylated CNWs. Those scaffolds exhibited both mechanical properties, due to carboxylated CNWs addition, and antimicrobial properties due to AgNPs. This type of nanocomposite exhibited sufficient protein adsorption and mineralization capacity which can overcome bone related infections like osteomyelitis [272]. Selenium nanoparticles (SeNPs), with their excellent antioxidant activity were used as nanofiller in chitosan films to produce electrical conductivity in cardiac patches. Due to its electrical and mechanical properties, this innovative material can be used in cardiac tissue engineering [273]. Nanocomposite films, obtained from PVA and zirconium phosphate doped with Ca, $\mathrm{Mg}$, and Ti nanoparticles were used for scaffold-guided tissue engineering application. It was observed that PVA films with Ca- doped ZrP nanoparticles had increased biological activity, whereas PVA films with Ti-doped $\mathrm{ZrP}$ nanoparticles had relatively higher mechanical properties [274]. Hydroxyapatite (HA) is the main component of inorganic bones and is a very good material for the development of internal scaffolds for bone repair [275]. HA nanoparticles promote adhesion, proliferation, and osteogenic differentiation of osteoblast-like cells therefore they were used in preparation of chitosan-HA nanocomposite films for bone tissue engineering application [276]. Arumugam and co-workers (2019) developed novel, porous, mechanically stable, hydrophilic nanocomposite polyvinylidene fluoride/poly(methyl methacrylate)/hydroxyapatite/ $\mathrm{TiO}_{2}$ film scaffolds. The in vitro study confirmed its excellent osteocompatibility, so this type of nanocomposite material could be used as potential material for bone repair applications [277]. The poly(L-lactic acid)/Ca-deficient-hydroxyapatite mats obtained by the electrospinning method can be used as a potential scaffold for bone marrow mesenchymal stem cell culture [278]. D'Angelo and coworkers (2012) investigated potential responses of multipotent (human-bone-marrow-derived mesenchymal stem cells) and pluripotent stem cells (murine-induced pluripotent stem cells and murine embryonic stem cells) to poly(L-lactic acid)/Ca-deficient-hydroxyapatite mats. They observed that the osteogenic differentiation effect of mats was not dependent on the type of stem cells [279].

In another work, HA was added to GO-chitosan films by using the layer-by-layer technique along with the biomimetic mineralization procedure. The results indicate the potential use of aspirin-loaded GO-chitosan-HA films in the field of bone tissue engineering [280].

\subsection{Other Applications}

Nanocomposite materials are also used in other industries. The addition of $\mathrm{ZnO}$ nanoparticles into chitosan/PVA films indicate their efficient removal of AB 1 azo dye (dye component) from aqueous solution [214]. The MWCNT was functionalized by valine and starch to improve the compatibility of MWCNT with chitosan/PVA matrix. The results indicate that this nanocomposite film is a very interesting adsorbent for the removal of Cd(II) from aqueous solutions [239].

Due to their inherent optical properties, the presence of carbon quantum dots in CMC films effectively caused ultraviolet light to convert into blue light. Transparent sunlight conversion CMC film with carbon quantum dots could be used in agriculture planting [281]. Mitta et al. (2018) obtained DNA thin films incorporated with AuNPs to demonstrate efficient UV photodetectors. Due to the presence of Au NPs, photodetectors were characterized by stability and durability [282]. 


\section{The Future of Nanomaterials}

According to the regulations of the European Commission, nanomaterials are covered by a regulatory framework. The presence of nanomaterials, including in food and cosmetics, must be indicated on the label in the list of ingredients. In addition, consumers must have access to online resources and databases on nanomaterials [253]. Due to the promising properties of nanomaterials, increasingly more new materials are appearing and the assessment of their risks requires an individual approach to each nanomaterial. There are major concerns that the high surface-to-volume ratio of nanomaterials may result in their having higher reactivity and potential toxicity. Due to the concerns about the safety of using nanomaterials, further research is necessary to give an unambiguous answer as to whether and which nanomaterials can be a viable alternative to traditional materials for application in many different areas [226,253].

Author Contributions: All the authors contributed equally.

Acknowledgments: The financial support from the projects CEITEC 2020 (LQ 1601) and EFRR project (no. CZ.02.1.01/0.0/0.0/16_025/0007314) is highly acknowledged.

Conflicts of Interest: The authors declare no conflict of interest.

\section{Abbreviations}

$\begin{array}{ll}\text { NPS } & \text { nanoparticles } \\ \text { CMC } & \text { carboxymethyl cellulose } \\ \text { PVA } & \text { poly(vinyl) alcohol } \\ \text { PLA } & \text { poly(lactic acid) } \\ \text { TS } & \text { tensile strength } \\ \text { EAB } & \text { elongation at break } \\ \text { YM } & \text { Young's modulus } \\ \text { EM } & \text { elastic modulus } \\ \text { WVP } & \text { water vapor permeability } \\ \text { OP } & \text { oxygen permeability } \\ \text { WS } & \text { water solubility } \\ \text { SR } & \text { swelling ratio } \\ \text { MC } & \text { moisture content } \\ \text { WCA } & \text { water contact angle }\end{array}$

\section{References}

1. George, J.; Ishida, H. A review on the very high nanofiller-content nanocomposites: Their preparation methods and properties with high aspect ratio fillers. Prog. Polym. Sci. 2018, 86, 1-39. [CrossRef]

2. El Achaby, M.; El Miri, N.; Aboulkas, A.; Zahouily, M.; Bilal, E.; Barakat, A.; Solhy, A. Processing and properties of eco-friendly bio-nanocomposite films filled with cellulose nanocrystals from sugarcane bagasse. Int. J. Biol. Macromol. 2017, 96, 340-352. [CrossRef]

3. Cacciotti, I.; Mori, S.; Cherubini, V.; Nanni, F. Eco-sustainable systems based on poly(lactic acid), diatomite and coffee grounds extract for food packaging. Int. J. Biol. Macromol. 2018, 112, 567-575. [CrossRef] [PubMed]

4. Sothornvit, R. Nanostructured materials for food packaging systems: New functional properties. Curr. Opin. Food Sci. 2019. [CrossRef]

5. Wu, Z.; Huang, X.; Li, Y.-C.; Xiao, H.; Wang, X. Novel chitosan films with laponite immobilized Ag nanoparticles for active food packaging. Carbohydr. Polym. 2018, 199, 210-218. [CrossRef]

6. Pinto, A.M.B.; Santos, T.M.; Caceres, C.A.; Lima, J.R.; Ito, E.N.; Azeredo, H.M.C. Starch-cashew tree gum nanocomposite films and their application for coating cashew nuts. LWT Food Sci. Technol. 2015, 62, 549-554. [CrossRef] 
7. Youssef, A.M.; El-Sayed, S.M.; Salama, H.H.; El-Sayed, H.S.; Dufresne, A. Evaluation of bionanocomposites as packaging material on properties of soft white cheese during storage period. Carbohydr. Polym. 2015, 132, 274-285. [CrossRef]

8. Lotfi, M.; Tajik, H.; Moradi, M.; Forough, M.; Divsalar, E.; Kuswandi, B. Nanostructured chitosan/ monolaurin film: Preparation, characterization and antimicrobial activity against Listeria monocytogenes on ultrafiltered white cheese. LWT 2018, 92, 576-583. [CrossRef]

9. Echeverría, I.; López-Caballero, M.E.; Gómez-Guillén, M.C.; Mauri, A.N.; Montero, M.P. Active nanocomposite films based on soy proteins-montmorillonite- clove essential oil for the preservation of refrigerated bluefin tuna (Thunnus thynnus) fillets. Int. J. Food Microbiol. 2018, 266, 142-149. [CrossRef] [PubMed]

10. Mathew, S.; Snigdha, S.; Mathew, J.; Radhakrishnan, E.K. Biodegradable and active nanocomposite pouches reinforced with silver nanoparticles for improved packaging of chicken sausages. Food Packag. Shelf Life 2019, 19, 155-166. [CrossRef]

11. Xu, Y.; Rehmani, N.; Alsubaie, L.; Kim, C.; Sismour, E.; Scales, A. Tapioca starch active nanocomposite films and their antimicrobial effectiveness on ready-to-eat chicken meat. Food Packag. Shelf Life 2018, 16, 86-91. [CrossRef]

12. Yu, Z.; Alsammarraie, F.K.; Nayigiziki, F.X.; Wang, W.; Vardhanabhuti, B.; Mustapha, A.; Lin, M. Effect and mechanism of cellulose nanofibrils on the active functions of biopolymer-based nanocomposite films. Food Res. Int. 2017, 99, 166-172. [CrossRef] [PubMed]

13. Xu, W.; Xie, W.; Huang, X.; Chen, X.; Huang, N.; Wang, X.; Liu, J. The graphene oxide and chitosan biopolymer loads $\mathrm{TiO} 2$ for antibacterial and preservative research. Food Chem. 2017, 221, 267-277. [CrossRef] [PubMed]

14. Luo, Z.; Qin, Y.; Ye, Q. Effect of nano- $\mathrm{TiO}_{2}-\mathrm{LDPE}$ packaging on microbiological and physicochemical quality of Pacific white shrimp during chilled storage. Int. J. Food Sci. Technol. 2015, 50, 1567-1573. [CrossRef]

15. Fang, D.; Yang, W.; Kimatu, B.M.; Mariga, A.M.; Zhao, L.; An, X.; Hu, Q. Effect of nanocomposite-based packaging on storage stability of mushrooms (Flammulina velutipes). Innov. Food Sci. Emerg. Technol. 2016, 33, 489-497. [CrossRef]

16. Majeed, K.; Jawaid, M.; Hassan, A.; Abu Bakar, A.; Abdul Khalil, H.P.S.; Salema, A.A.; Inuwa, I. Potential materials for food packaging from nanoclay/natural fibres filled hybrid composites. Mater. Des. 2013, 46, 391-410. [CrossRef]

17. Othman, S.H. Bio-nanocomposite Materials for Food Packaging Applications: Types of Biopolymer and Nano-sized Filler. Agric. Agric. Sci. Procedia 2014, 2, 296-303. [CrossRef]

18. Xiong, R.; Grant, A.M.; Ma, R.; Zhang, S.; Tsukruk, V.V. Naturally-derived biopolymer nanocomposites: Interfacial design, properties and emerging applications. Mater. Sci. Eng. R Rep. 2018, 125, 1-41. [CrossRef]

19. Garavand, F.; Rouhi, M.; Razavi, S.H.; Cacciotti, I.; Mohammadi, R. Improving the integrity of natural biopolymer films used in food packaging by crosslinking approach: A review. Int. J. Biol. Macromol. 2017, 104, 687-707. [CrossRef]

20. Sharma, B.; Malik, P.; Jain, P. Biopolymer reinforced nanocomposites: A comprehensive review. Mater. Today Commun. 2018, 16, 353-363. [CrossRef]

21. Rouf, T.B.; Kokini, J.L. Biodegradable biopolymer-graphene nanocomposites. J. Mater. Sci. 2016, 51, 9915-9945. [CrossRef]

22. Zare, Y.; Shabani, I. Polymer/metal nanocomposites for biomedical applications. Mater. Sci. Eng. C 2016, 60, 195-203. [CrossRef] [PubMed]

23. Mujtaba, M.; Morsi, R.E.; Kerch, G.; Elsabee, M.Z.; Kaya, M.; Labidi, J.; Khawar, K.M. Current advancements in chitosan-based film production for food technology: A review. Int. J. Biol. Macromol. 2019, 121, 889-904. [CrossRef]

24. Ogunsona, E.; Ojogbo, E.; Mekonnen, T. Advanced material applications of starch and its derivatives. Eur. Polym. J. 2018, 108, 570-581. [CrossRef]

25. Singh, R.S.; Kaur, N.; Rana, V.; Kennedy, J.F. Pullulan: A novel molecule for biomedical applications. Carbohydr. Polym. 2017, 171, 102-121. [CrossRef]

26. Horinaka, J.-I.; Hashimoto, Y.; Takigawa, T. Optical and mechanical properties of pullulan films studied by uniaxial stretching. Int. J. Biol. Macromol. 2018, 118, 584-587. [CrossRef] [PubMed] 
27. Hassan, B.; Chatha, S.A.S.; Hussain, A.I.; Zia, K.M.; Akhtar, N. Recent advances on polysaccharides, lipids and protein based edible films and coatings: A review. Int. J. Biol. Macromol. 2018, 109, 1095-1107. [CrossRef] [PubMed]

28. Bahrami, A.; Rezaei Mokarram, R.; Sowti Khiabani, M.; Ghanbarzadeh, B.; Salehi, R. Physico-mechanical and antimicrobial properties of tragacanth/hydroxypropyl methylcellulose/beeswax edible films reinforced with silver nanoparticles. Int. J. Biol. Macromol. 2018. [CrossRef] [PubMed]

29. Velickova, E.; Winkelhausen, E.; Kuzmanova, S.; Alves, V.D.; Moldão-Martins, M. Impact of chitosan-beeswax edible coatings on the quality of fresh strawberries (Fragaria ananassa cv Camarosa) under commercial storage conditions. LWT Food Sci. Technol. 2013, 52, 80-92. [CrossRef]

30. Nofar, M.; Sacligil, D.; Carreau, P.J.; Kamal, M.R.; Heuzey, M.-C. Poly (lactic acid) blends: Processing, properties and applications. Int. J. Biol. Macromol. 2019, 125, 307-360. [CrossRef]

31. Shankar, S.; Wang, L.-F.; Rhim, J.-W. Incorporation of zinc oxide nanoparticles improved the mechanical, water vapor barrier, UV-light barrier, and antibacterial properties of PLA-based nanocomposite films. Mater. Sci. Eng. C 2018, 93, 289-298. [CrossRef] [PubMed]

32. Thong, C.C.; Teo, D.C.L.; Ng, C.K. Application of polyvinyl alcohol (PVA) in cement-based composite materials: A review of its engineering properties and microstructure behavior. Constr. Build. Mater. 2016, 107, 172-180. [CrossRef]

33. Hoque, M.A.; Ahmed, M.R.; Rahman, G.T.; Rahman, M.T.; Islam, M.A.; Khan, M.A.; Hossain, M.K. Fabrication and comparative study of magnetic $\mathrm{Fe}$ and $\alpha-\mathrm{Fe}_{2} \mathrm{O}_{3}$ nanoparticles dispersed hybrid polymer (PVA + Chitosan) novel nanocomposite film. Results Phys. 2018, 10, 434-443. [CrossRef]

34. Martínez-Sanz, M.; Villano, M.; Oliveira, C.; Albuquerque, M.G.E.; Majone, M.; Reis, M.; Lopez-Rubio, A.; Lagaron, J.M. Characterization of polyhydroxyalkanoates synthesized from microbial mixed cultures and of their nanobiocomposites with bacterial cellulose nanowhiskers. New Biotechnol. 2014, 31, 364-376. [CrossRef]

35. Bianco, A.; Di Federico, E.; Cacciotti, I. Electrospun poly( $\varepsilon$-caprolactone)-based composites using synthesized $\beta$-tricalcium phosphate. Polym. Adv. Technol. 2011, 22, 1832-1841. [CrossRef]

36. Liu, M.; Zhang, T.; Long, L.; Zhang, R.; Ding, S. Efficient enzymatic degradation of poly ( $\varepsilon$-caprolactone) by an engineered bifunctional lipase-cutinase. Polym. Degrad. Stab. 2019, 160, 120-125. [CrossRef]

37. Bianco, A.; Calderone, M.; Cacciotti, I. Electrospun PHBV/PEO co-solution blends: Microstructure, thermal and mechanical properties. Mater. Sci. Eng. C 2013, 33, 1067-1077. [CrossRef]

38. Cacciotti, I.; Calderone, M.; Bianco, A. Tailoring the properties of electrospun PHBV mats: Co-solution blending and selective removal of PEO. Eur. Polym. J. 2013, 49, 3210-3222. [CrossRef]

39. Wang, S.; Lu, A.; Zhang, L. Recent advances in regenerated cellulose materials. Prog. Polym. Sci. 2016, 53, 169-206. [CrossRef]

40. Wang, Y.; Liu, L.; Chen, P.; Zhang, L.; Lu, A. Cationic hydrophobicity promotes dissolution of cellulose in aqueous basic solution by freezing-thawing. Phys. Chem. Chem. Phys. PCCP 2018, 20, 14223-14233. [CrossRef]

41. Wu, Y.; Li, Q.; Zhang, X.; Li, Y.; Li, B.; Liu, S. Cellulose-based peptidopolysaccharides as cationic antimicrobial package films. Int. J. Biol. Macromol. 2019, 128, 673-680. [CrossRef]

42. Dutta, P.K.; Tripathi, S.; Mehrotra, G.K.; Dutta, J. Perspectives for chitosan based antimicrobial films in food applications. Food Chem. 2009, 114, 1173-1182. [CrossRef]

43. Devlieghere, F.; Vermeulen, A.; Debevere, J. Chitosan: Antimicrobial activity, interactions with food components and applicability as a coating on fruit and vegetables. Food Microbiol. 2004, 21, 703-714. [CrossRef]

44. Rambabu, K.; Bharath, G.; Banat, F.; Show, P.L.; Cocoletzi, H.H. Mango leaf extract incorporated chitosan antioxidant film for active food packaging. Int. J. Biol. Macromol. 2019, 126, 1234-1243. [CrossRef]

45. Jiang, Z.; Neetoo, H.; Chen, H. Efficacy of freezing, frozen storage and edible antimicrobial coatings used in combination for control of Listeria monocytogenes on roasted turkey stored at chiller temperatures. Food Microbiol. 2011, 28, 1394-1401. [CrossRef]

46. Thakur, R.; Pristijono, P.; Scarlett, C.J.; Bowyer, M.; Singh, S.P.; Vuong, Q.V. Starch-based films: Major factors affecting their properties. Int. J. Biol. Macromol. 2019. [CrossRef] [PubMed]

47. Silva, A.P.M.; Oliveira, A.V.; Pontes, S.M.A.; Pereira, A.L.S.; Souza Filho, M.d.s.M.; Rosa, M.F.; Azeredo, H.M.C. Mango kernel starch films as affected by starch nanocrystals and cellulose nanocrystals. Carbohydr. Polym. 2019, 211, 209-216. [CrossRef] [PubMed] 
48. Younis, H.G.R.; Zhao, G. Physicochemical properties of the edible films from the blends of high methoxyl apple pectin and chitosan. Int. J. Biol. Macromol. 2019, 131, 1057-1066. [CrossRef] [PubMed]

49. Spatafora Salazar, A.S.; Sáenz Cavazos, P.A.; Mújica Paz, H.; Valdez Fragoso, A. External factors and nanoparticles effect on water vapor permeability of pectin-based films. J. Food Eng. 2019, 245, 73-79. [CrossRef]

50. Niu, B.; Shao, P.; Chen, H.; Sun, P. Structural and physiochemical characterization of novel hydrophobic packaging films based on pullulan derivatives for fruits preservation. Carbohydr. Polym. 2019, 208, 276-284. [CrossRef]

51. Chu, Y.; Xu, T.; Gao, C.; Liu, X.; Zhang, N.; Feng, X.; Liu, X.; Shen, X.; Tang, X. Evaluations of physicochemical and biological properties of pullulan-based films incorporated with cinnamon essential oil and Tween 80. Int. J. Biol. Macromol. 2019, 122, 388-394. [CrossRef]

52. Kim, J.-Y.; Choi, Y.-G.; Byul Kim, S.R.; Lim, S.-T. Humidity stability of tapioca starch-pullulan composite films. Food Hydrocoll. 2014, 41, 140-145. [CrossRef]

53. Salama, H.E.; Abdel Aziz, M.S.; Sabaa, M.W. Novel biodegradable and antibacterial edible films based on alginate and chitosan biguanidine hydrochloride. Int. J. Biol. Macromol. 2018, 116, 443-450. [CrossRef] [PubMed]

54. Li, K.; Zhu, J.; Guan, G.; Wu, H. Preparation of chitosan-sodium alginate films through layer-by-layer assembly and ferulic acid crosslinking: Film properties, characterization, and formation mechanism. Int. J. Biol. Macromol. 2019, 122, 485-492. [CrossRef] [PubMed]

55. Molinaro, S.; Cruz-Romero, M.; Sensidoni, A.; Morris, M.; Lagazio, C.; Kerry, J.P. Combination of high-pressure treatment, mild heating and holding time effects as a means of improving the barrier properties of gelatin-based packaging films using response surface modeling. Innov. Food Sci. Emerg. Technol. 2015, 30, 15-23. [CrossRef]

56. Hanani, Z.A.N.; Yee, F.C.; Nor-Khaizura, M.A.R. Effect of pomegranate (Punica granatum L.) peel powder on the antioxidant and antimicrobial properties of fish gelatin films as active packaging. Food Hydrocoll. 2019, 89, 253-259. [CrossRef]

57. Chiumarelli, M.; Hubinger, M.D. Stability, solubility, mechanical and barrier properties of cassava starch Carnauba wax edible coatings to preserve fresh-cut apples. Food Hydrocoll. 2012, 28, 59-67. [CrossRef]

58. Torres, F.G.; Arroyo, J.J.; Troncoso, O.P. Bacterial cellulose nanocomposites: An all-nano type of material. Mater. Sci. Eng. C 2019, 98, 1277-1293. [CrossRef]

59. Silva, R.D.; Sierakowski, M.R.; Bassani, H.P.; Zawadzki, S.F.; Pirich, C.L.; Ono, L.; de Freitas, R.A. Hydrophilicity improvement of mercerized bacterial cellulose films by polyethylene glycol graft. Int. J. Biol. Macromol. 2016, 86, 599-605. [CrossRef]

60. Chang, H.-M.; Prasannan, A.; Tsai, H.-C.; Jhu, J.-J. Ex vivo evaluation of biodegradable poly( $\varepsilon$-caprolactone) films in digestive fluids. Appl. Surf. Sci. 2014, 313, 828-833. [CrossRef]

61. Mosnáček, J.; Borská, K.; Danko, M.; Janigová, I. Photochemically promoted degradation of poly( $\varepsilon$-caprolactone) film. Mater. Chem. Phys. 2013, 140, 191-199. [CrossRef]

62. Wang, Z.; Yao, Z.; Zhou, J.; He, M.; Jiang, Q.; Li, A.; Li, S.; Liu, M.; Luo, S.; Zhang, D. Improvement of polylactic acid film properties through the addition of cellulose nanocrystals isolated from waste cotton cloth. Int. J. Biol. Macromol. 2019, 129, 878-886. [CrossRef] [PubMed]

63. Murariu, M.; Dubois, P. PLA composites: From production to properties. Adv. Drug Deliv. Rev. 2016, 107, 17-46. [CrossRef] [PubMed]

64. Mhiri, S.; Mignard, N.; Abid, M.; Prochazka, F.; Majeste, J.-C.; Taha, M. Thermally reversible and biodegradable polyglycolic-acid-based networks. Eur. Polym. J. 2017, 88, 292-310. [CrossRef]

65. You, Y.; Min, B.-M.; Lee, S.J.; Lee, T.S.; Park, W.H. In vitro degradation behavior of electrospun polyglycolide, polylactide, and poly(lactide-co-glycolide). J. Appl. Polym. Sci. 2005, 95, 193-200. [CrossRef]

66. Fu, C.; Hu, X.; Yang, Z.; Shen, L.; Zheng, Z. Preparation and properties of waterborne bio-based polyurethane/siloxane cross-linked films by an in situ sol-gel process. Prog. Org. Coat. 2015, 84, 18-27. [CrossRef]

67. Youssef, A.M.; El-Sayed, S.M. Bionanocomposites materials for food packaging applications: Concepts and future outlook. Carbohydr. Polym. 2018, 193, 19-27. [CrossRef]

68. Nasrollahzadeh, M.; Issaabadi, Z.; Sajjadi, M.; Sajadi, S.M.; Atarod, M. Chapter 2-Types of Nanostructures. In Interface Science and Technology; Nasrollahzadeh, M., Sajadi, S.M., Sajjadi, M., Issaabadi, Z., Atarod, M., Eds.; Elsevier: Amsterdam, The Netherlands, 2019; Volume 28, pp. $29-80$. 
69. Fathi Achachlouei, B.; Zahedi, Y. Fabrication and characterization of CMC-based nanocomposites reinforced with sodium montmorillonite and $\mathrm{TiO}_{2}$ nanomaterials. Carbohydr. Polym. 2018, 199, 415-425. [CrossRef]

70. Zhu, T.T.; Zhou, C.H.; Kabwe, F.B.; Wu, Q.Q.; Li, C.S.; Zhang, J.R. Exfoliation of montmorillonite and related properties of clay/polymer nanocomposites. Appl. Clay Sci. 2019, 169, 48-66. [CrossRef]

71. Poonguzhali, R.; Basha, S.K.; Kumari, V.S. Synthesis and characterization of chitosan-PVP-nanocellulose composites for in-vitro wound dressing application. Int. J. Biol. Macromol. 2017, 105, 111-120. [CrossRef] [PubMed]

72. Adel, A.; El-Shafei, A.; Ibrahim, A.; Al-Shemy, M. Extraction of oxidized nanocellulose from date palm (Phoenix dactylifera L.) sheath fibers: Influence of CI and CII polymorphs on the properties of chitosan/bionanocomposite films. Ind. Crops Prod. 2018, 124, 155-165. [CrossRef]

73. Curvello, R.; Raghuwanshi, V.S.; Garnier, G. Engineering nanocellulose hydrogels for biomedical applications. Adv. Coll. Interface Sci. 2019, 267, 47-61. [CrossRef] [PubMed]

74. Yu, S.; Xu, X.; Feng, J.; Liu, M.; Hu, K. Chitosan and chitosan coating nanoparticles for the treatment of brain disease. Int. J. Pharm. 2019, 560, 282-293. [CrossRef]

75. Martins, G.O.; Segalla Petrônio, M.; Furuyama Lima, A.M.; Martinez Junior, A.M.; de Oliveira Tiera, V.A.; de Freitas Calmon, M.; Leite Vilamaior, P.S.; Han, S.W.; Tiera, M.J. Amphipathic Chitosans Improve the Physicochemical Properties of siRNA-Chitosan Nanoparticles at Physiological Conditions. Carbohydr. Polym. 2019. [CrossRef]

76. Pan, C.; Qian, J.; Fan, J.; Guo, H.; Gou, L.; Yang, H.; Liang, C. Preparation nanoparticle by ionic cross-linked emulsified chitosan and its antibacterial activity. Colloids Surf. A Physicochem. Eng. Aspects 2019, 568, 362-370. [CrossRef]

77. Divya, M.; Kiran, G.S.; Hassan, S.; Selvin, J. Biogenic synthesis and effect of silver nanoparticles (AgNPs) to combat catheter-related urinary tract infections. Biocatal. Agric. Biotechnol. 2019, 18, 101037. [CrossRef]

78. Roy, S.; Shankar, S.; Rhim, J.-W. Melanin-mediated synthesis of silver nanoparticle and its use for the preparation of carrageenan-based antibacterial films. Food Hydrocoll. 2019, 88, 237-246. [CrossRef]

79. Kadam, D.; Momin, B.; Palamthodi, S.; Lele, S.S. Physicochemical and functional properties of chitosan-based nano-composite films incorporated with biogenic silver nanoparticles. Carbohydr. Polym. 2019, 211, 124-132. [CrossRef]

80. Farshchi, E.; Pirsa, S.; Roufegarinejad, L.; Alizadeh, M.; Rezazad, M. Photocatalytic/biodegradable film based on carboxymethyl cellulose, modified by gelatin and $\mathrm{TiO}_{2}-\mathrm{Ag}$ nanoparticles. Carbohydr. Polym. 2019. [CrossRef]

81. Jamróz, E.; Kopel, P.; Juszczak, L.; Kawecka, A.; Bytesnikova, Z.; Milosavljević, V.; Kucharek, M.; Makarewicz, M.; Adam, V. Development and characterisation of furcellaran-gelatin films containing SeNPs and AgNPs that have antimicrobial activity. Food Hydrocoll. 2018, 83, 9-16. [CrossRef]

82. Kalishwaralal, K.; Jeyabharathi, S.; Sundar, K.; Muthukumaran, A. A novel one-pot green synthesis of selenium nanoparticles and evaluation of its toxicity in zebrafish embryos. Artif. Cells Nanomed. Biotechnol. 2016, 44, 471-477. [CrossRef] [PubMed]

83. Shankar, S.; Teng, X.; Rhim, J.-W. Properties and characterization of agar/CuNP bionanocomposite films prepared with different copper salts and reducing agents. Carbohydr. Polym. 2014, 114, 484-492. [CrossRef]

84. Roy, S.; Rhim, J.-W.; Jaiswal, L. Bioactive agar-based functional composite film incorporated with copper sulfide nanoparticles. Food Hydrocoll. 2019, 93, 156-166. [CrossRef]

85. Shankar, S.; Rhim, J.-W. Preparation of sulfur nanoparticle-incorporated antimicrobial chitosan films. Food Hydrocoll. 2018, 82, 116-123. [CrossRef]

86. Natarajan, S.; Lakshmi, D.S.; Thiagarajan, V.; Mrudula, P.; Chandrasekaran, N.; Mukherjee, A. Antifouling and anti-algal effects of chitosan nanocomposite $\left(\mathrm{TiO}_{2} / \mathrm{Ag}\right)$ and pristine $\left(\mathrm{TiO}_{2}\right.$ and $\left.\mathrm{Ag}\right)$ films on marine microalgae Dunaliella salina. J. Environ. Chem. Eng. 2018, 6, 6870-6880. [CrossRef]

87. Alizadeh-Sani, M.; Khezerlou, A.; Ehsani, A. Fabrication and characterization of the bionanocomposite film based on whey protein biopolymer loaded with $\mathrm{TiO} 2$ nanoparticles, cellulose nanofibers and rosemary essential oil. Ind. Crops Prod. 2018, 124, 300-315. [CrossRef]

88. Jbeli, A.; Hamden, Z.; Bouattour, S.; Ferraria, A.M.; Conceição, D.S.; Ferreira, L.F.V.; Chehimi, M.M.; do Rego, A.M.B.; Rei Vilar, M.; Boufi, S. Chitosan-Ag-TiO 2 films: An effective photocatalyst under visible light. Carbohydr. Polym. 2018, 199, 31-40. [CrossRef] 
89. Noshirvani, N.; Ghanbarzadeh, B.; Mokarram, R.R.; Hashemi, M.; Coma, V. Preparation and characterization of active emulsified films based on chitosan-carboxymethyl cellulose containing zinc oxide nano particles. Int. J. Biol. Macromol. 2017, 99, 530-538. [CrossRef] [PubMed]

90. Abdeen, Z.I.; El Farargy, A.F.; Negm, N.A. Nanocomposite framework of chitosan/polyvinyl alcohol/ZnO: Preparation, characterization, swelling and antimicrobial evaluation. J. Mol. Liquids 2018, 250, 335-343. [CrossRef]

91. Ponnamma, D.; Cabibihan, J.-J.; Rajan, M.; Pethaiah, S.S.; Deshmukh, K.; Gogoi, J.P.; Pasha, S.K.K.; Ahamed, M.B.; Krishnegowda, J.; Chandrashekar, B.N.; et al. Synthesis, optimization and applications of ZnO/polymer nanocomposites. Mater. Sci. Eng. C 2019, 98, 1210-1240. [CrossRef] [PubMed]

92. Tripathi, R.; Narayan, A.; Bramhecha, I.; Sheikh, J. Development of multifunctional linen fabric using chitosan film as a template for immobilization of in-situ generated $\mathrm{CeO} 2$ nanoparticles. Int. J. Biol. Macromol. 2019, 121, 1154-1159. [CrossRef]

93. Wang, C.; Murugadoss, V.; Kong, J.; He, Z.; Mai, X.; Shao, Q.; Chen, Y.; Guo, L.; Liu, C.; Angaiah, S.; et al. Overview of carbon nanostructures and nanocomposites for electromagnetic wave shielding. Carbon 2018, 140, 696-733. [CrossRef]

94. Wu, Q.; Sun, Y.; Gao, J.; Dong, S.; Luo, G.; Li, H.; Zhao, L. Applications of hybrid organic-inorganic materials in chiral separation. TrAC Trends Anal. Chem. 2017, 95, 140-148. [CrossRef]

95. Shankar, S.; Kasapis, S.; Rhim, J.-W. Alginate-based nanocomposite films reinforced with halloysite nanotubes functionalized by alkali treatment and zinc oxide nanoparticles. Int. J. Biol. Macromol. 2018, 118, 1824-1832. [CrossRef] [PubMed]

96. Zhang, Y.; Chen, Y.; Zhang, H.; Zhang, B.; Liu, J. Potent antibacterial activity of a novel silver nanoparticle-halloysite nanotube nanocomposite powder. J. Inorg. Biochem. 2013, 118, 59-64. [CrossRef] [PubMed]

97. Chen, Y.; Zhang, Y.; Liu, J.; Zhang, H.; Wang, K. Preparation and antibacterial property of polyethersulfone ultrafiltration hybrid membrane containing halloysite nanotubes loaded with copper ions. Chem. Eng. J. 2012, 210, 298-308. [CrossRef]

98. Ling, S.; Chen, W.; Fan, Y.; Zheng, K.; Jin, K.; Yu, H.; Buehler, M.J.; Kaplan, D.L. Biopolymer nanofibrils: Structure, modeling, preparation, and applications. Prog. Polym. Sci. 2018, 85, 1-56. [CrossRef]

99. Abdul Khalil, H.P.S.; Bhat, A.H.; Ireana Yusra, A.F. Green composites from sustainable cellulose nanofibrils: A review. Carbohydr. Polym. 2012, 87, 963-979. [CrossRef]

100. Phanthong, P.; Reubroycharoen, P.; Hao, X.; Xu, G.; Abudula, A.; Guan, G. Nanocellulose: Extraction and application. Carbon Resour. Convers. 2018, 1, 32-43. [CrossRef]

101. Mishra, S.; Kharkar, P.S.; Pethe, A.M. Biomass and waste materials as potential sources of nanocrystalline cellulose: Comparative review of preparation methods (2016-Till date). Carbohydr. Polym. 2019, 207, 418-427. [CrossRef]

102. Oun, A.A.; Rhim, J.-W. Isolation of cellulose nanocrystals from grain straws and their use for the preparation of carboxymethyl cellulose-based nanocomposite films. Carbohydr. Polym. 2016, 150, 187-200. [CrossRef] [PubMed]

103. Niamsap, T.; Lam, N.T.; Sukyai, P. Production of hydroxyapatite-bacterial nanocellulose scaffold with assist of cellulose nanocrystals. Carbohydr. Polym. 2019, 205, 159-166. [CrossRef] [PubMed]

104. Bao, Y.; Zhang, H.; Luan, Q.; Zheng, M.; Tang, H.; Huang, F. Fabrication of cellulose nanowhiskers reinforced chitosan-xylan nanocomposite films with antibacterial and antioxidant activities. Carbohydr. Polym. 2018, 184, 66-73. [CrossRef] [PubMed]

105. Rouhi, M.; Razavi, S.H.; Mousavi, S.M. Optimization of crosslinked poly(vinyl alcohol) nanocomposite films for mechanical properties. Mater. Sci. Eng. C 2017, 71, 1052-1063. [CrossRef] [PubMed]

106. Marín-Silva, D.A.; Rivero, S.; Pinotti, A. Chitosan-based nanocomposite matrices: Development and characterization. Int. J. Biol. Macromol. 2019, 123, 189-200. [CrossRef] [PubMed]

107. Cacciotti, I.; Fortunati, E.; Puglia, D.; Kenny, J.M.; Nanni, F. Effect of silver nanoparticles and cellulose nanocrystals on electrospun poly(lactic) acid mats: Morphology, thermal properties and mechanical behavior. Carbohydr. Polym. 2014, 103, 22-31. [CrossRef]

108. Olivera, S.; Muralidhara, H.B.; Venkatesh, K.; Guna, V.K.; Gopalakrishna, K.; Kumar, Y. Potential applications of cellulose and chitosan nanoparticles/composites in wastewater treatment: A review. Carbohydr. Polym. 2016, 153, 600-618. [CrossRef] 
109. Azarifar, M.; Ghanbarzadeh, B.; Sowti Khiabani, M.; Akhondzadeh Basti, A.; Abdulkhani, A.; Noshirvani, N.; Hosseini, M. The optimization of gelatin-CMC based active films containing chitin nanofiber and Trachyspermum ammi essential oil by response surface methodology. Carbohydr. Polym. 2019, 208, 457-468. [CrossRef]

110. Hassan, E.A.; Hassan, M.L.; Abou-zeid, R.E.; El-Wakil, N.A. Novel nanofibrillated cellulose/chitosan nanoparticles nanocomposites films and their use for paper coating. Ind. Crops Prod. 2016, 93, 219-226. [CrossRef]

111. Ma, Q.; Liang, T.; Cao, L.; Wang, L. Intelligent poly (vinyl alcohol)-chitosan nanoparticles-mulberry extracts films capable of monitoring $\mathrm{pH}$ variations. Int. J. Biol. Macromol. 2018, 108, 576-584. [CrossRef]

112. Vahedikia, N.; Garavand, F.; Tajeddin, B.; Cacciotti, I.; Jafari, S.M.; Omidi, T.; Zahedi, Z. Biodegradable zein film composites reinforced with chitosan nanoparticles and cinnamon essential oil: Physical, mechanical, structural and antimicrobial attributes. Colloids Surf. B Biointerfaces 2019, 177, 25-32. [CrossRef] [PubMed]

113. Naskar, S.; Sharma, S.; Kuotsu, K. Chitosan-based nanoparticles: An overview of biomedical applications and its preparation. J. Drug Delivery Sci. Technol. 2019, 49, 66-81. [CrossRef]

114. Sengan, M.; Subramaniyan, S.B.; Arul Prakash, S.; Kamlekar, R.; Veerappan, A. Effective elimination of biofilm formed with waterborne pathogens using copper nanoparticles. Microb. Pathog. 2019, 127, 341-346. [CrossRef]

115. Kumar, S.S.D.; Rajendran, N.K.; Houreld, N.N.; Abrahamse, H. Recent advances on silver nanoparticle and biopolymer-based biomaterials for wound healing applications. Int. J. Biol. Macromol. 2018, 115, 165-175. [CrossRef] [PubMed]

116. Carbone, M.; Donia, D.T.; Sabbatella, G.; Antiochia, R. Silver nanoparticles in polymeric matrices for fresh food packaging. J. King Saud Univ. Sci. 2016, 28, 273-279. [CrossRef]

117. Park, S.-B.; Lih, E.; Park, K.-S.; Joung, Y.K.; Han, D.K. Biopolymer-based functional composites for medical applications. Prog. Polym. Sci. 2017, 68, 77-105. [CrossRef]

118. Khurana, A.; Tekula, S.; Saifi, M.A.; Venkatesh, P.; Godugu, C. Therapeutic applications of selenium nanoparticles. Biomed. Pharmacother. 2019, 111, 802-812. [CrossRef]

119. Garcia, C.V.; Shin, G.H.; Kim, J.T. Metal oxide-based nanocomposites in food packaging: Applications, migration, and regulations. Trends Food Sci. Technol. 2018, 82, 21-31. [CrossRef]

120. Król, A.; Pomastowski, P.; Rafińska, K.; Railean-Plugaru, V.; Buszewski, B. Zinc oxide nanoparticles: Synthesis, antiseptic activity and toxicity mechanism. Adv. Colloid Interface Sci. 2017, 249, 37-52. [CrossRef]

121. Oleyaei, S.A.; Zahedi, Y.; Ghanbarzadeh, B.; Moayedi, A.A. Modification of physicochemical and thermal properties of starch films by incorporation of TiO2 nanoparticles. Int. J. Biol. Macromol. 2016, 89, $256-264$. [CrossRef]

122. Deka, B.K.; Kong, K.; Seo, J.; Kim, D.; Park, Y.-B.; Park, H.W. Controlled growth of CuO nanowires on woven carbon fibers and effects on the mechanical properties of woven carbon fiber/polyester composites. Compos. Part A Appl. Sci. Manuf. 2015, 69, 56-63. [CrossRef]

123. Ebnalwaled, A.A.; Ismaiel, A.M. Developing novel UV shielding films based on PVA/Gelatin/0.01CuO nanocomposite: On the properties optimization using $\gamma$-irradiation. Measurement 2019, 134, 89-100. [CrossRef]

124. Zhao, Q.; Ma, L.; Zhang, Q.; Wang, C.; Xu, X. SnO -Based Nanomaterials: Synthesis and Application in Lithium-Ion Batteries and Supercapacitors. J. Nanomater. 2015, 2015, 805147. [CrossRef]

125. Baniasad, A.; Ghorbani, M. Thermal stability enhancement of modified carboxymethyl cellulose films using SnO2 nanoparticles. Int. J. Biol. Macromol. 2016, 86, 901-906. [CrossRef]

126. Bala, T.; Armstrong, G.; Laffir, F.; Thornton, R. Titania-silver and alumina-silver composite nanoparticles: Novel, versatile synthesis, reaction mechanism and potential antimicrobial application. J. Colloid Interface Sci. 2011, 356, 395-403. [CrossRef] [PubMed]

127. Moradi, Z.; Esmaiili, M.; Almasi, H. Development and characterization of kefiran- $\mathrm{Al}_{2} \mathrm{O}_{3}$ nanocomposite films: Morphological, physical and mechanical properties. Int. J. Biol. Macromol. 2019, 122, 603-609. [CrossRef] [PubMed]

128. Tong, Y.; Lin, Y.; Wang, S.; Song, M. A study of crystallisation of poly (ethylene oxide) and polypropylene on graphene surface. Polymer 2015, 73, 52-61. [CrossRef]

129. Gan, S.; Zakaria, S.; Syed Jaafar, S.N. Enhanced mechanical properties of hydrothermal carbamated cellulose nanocomposite film reinforced with graphene oxide. Carbohydr. Polym. 2017, 172, 284-293. [CrossRef] 
130. Kwak, H.W.; Shin, M.; Yun, H.; Lee, K.H. Preparation of Silk Sericin/Lignin Blend Beads for the Removal of Hexavalent Chromium Ions. Int. J. Mol. Sci. 2016, 17, 1466. [CrossRef]

131. Abdulkhani, A.; Daliri Sousefi, M.; Ashori, A.; Ebrahimi, G. Preparation and characterization of sodium carboxymethyl cellulose/silk fibroin/graphene oxide nanocomposite films. Polym. Test. 2016, 52, 218-224. [CrossRef]

132. Kakaei, K.; Marzang, K. One - Step synthesis of nitrogen doped reduced graphene oxide with NiCo nanoparticles for ethanol oxidation in alkaline media. J. Colloid Interface Sci. 2016, 462, 148-153. [CrossRef] [PubMed]

133. Liang, R.; Yan, D.; Tian, R.; Yu, X.; Shi, W.; Li, C.; Wei, M.; Evans, D.G.; Duan, X. Quantum Dots-Based Flexible Films and Their Application as the Phosphor in White Light-Emitting Diodes. Chem. Mater. 2014, 26, 2595-2600. [CrossRef]

134. Guo, Y.; Ge, X.; Guan, J.; Wu, L.; Zhao, F.; Li, H.; Mu, X.; Jiang, Y.; Chen, A. A novel method for fabricating hybrid bio-based nanocomposites film with stable fluorescence containing CdTe quantum dots and montmorillonite-chitosan nanosheets. Carbohydr. Polym. 2016, 145, 13-19. [CrossRef]

135. Javanbakht, S.; Namazi, H. Solid state photoluminescence thermoplastic starch film containing graphene quantum dots. Carbohydr. Polym. 2017, 176, 220-226. [CrossRef] [PubMed]

136. Hosseini, S.F.; Rezaei, M.; Zandi, M.; Farahmandghavi, F. Development of bioactive fish gelatin/chitosan nanoparticles composite films with antimicrobial properties. Food Chem. 2016, 194, 1266-1274. [CrossRef] [PubMed]

137. Chen, Y.; Liu, C.; Chang, P.R.; Anderson, D.P.; Huneault, M.A. Pea starch-based composite films with pea hull fibers and pea hull fiber-derived nanowhiskers. Polym. Eng. Sci. 2009, 49, 369-378. [CrossRef]

138. Noshirvani, N.; Hong, W.; Ghanbarzadeh, B.; Fasihi, H.; Montazami, R. Study of cellulose nanocrystal doped starch-polyvinyl alcohol bionanocomposite films. Int. J. Biol. Macromol. 2018, 107, 2065-2074. [CrossRef] [PubMed]

139. Hasheminya, S.-M.; Mokarram, R.R.; Ghanbarzadeh, B.; Hamishekar, H.; Kafil, H.S.; Dehghannya, J. Influence of simultaneous application of copper oxide nanoparticles and Satureja Khuzestanica essential oil on properties of kefiran-carboxymethyl cellulose films. Polym. Test. 2019, 73, 377-388. [CrossRef]

140. Alipoormazandarani, N.; Ghazihoseini, S.; Mohammadi Nafchi, A. Preparation and characterization of novel bionanocomposite based on soluble soybean polysaccharide and halloysite nanoclay. Carbohydr. Polym. 2015, 134, 745-751. [CrossRef]

141. Zolfi, M.; Khodaiyan, F.; Mousavi, M.; Hashemi, M. The improvement of characteristics of biodegradable films made from kefiran-whey protein by nanoparticle incorporation. Carbohydr. Polym. 2014, 109, 118-125. [CrossRef]

142. Hassannia-Kolaee, M.; Khodaiyan, F.; Pourahmad, R.; Shahabi-Ghahfarrokhi, I. Development of ecofriendly bionanocomposite: Whey protein isolate/pullulan films with nano-SiO 2 . Int. J. Biol. Macromol. 2016, 86, 139-144. [CrossRef]

143. Qin, Y.; Zhang, S.; Yu, J.; Yang, J.; Xiong, L.; Sun, Q. Effects of chitin nano-whiskers on the antibacterial and physicochemical properties of maize starch films. Carbohydr. Polym. 2016, 147, 372-378. [CrossRef] [PubMed]

144. Jafari, H.; Pirouzifard, M.; Khaledabad, M.A.; Almasi, H. Effect of chitin nanofiber on the morphological and physical properties of chitosan/silver nanoparticle bionanocomposite films. Int. J. Biol. Macromol. 2016, 92, 461-466. [CrossRef] [PubMed]

145. Devi, N.; Dutta, J. Development and in vitro characterization of chitosan/starch/halloysite nanotubes ternary nanocomposite films. Int. J. Biol. Macromol. 2019, 127, 222-231. [CrossRef]

146. Vejdan, A.; Ojagh, S.M.; Adeli, A.; Abdollahi, M. Effect of $\mathrm{TiO}_{2}$ nanoparticles on the physico-mechanical and ultraviolet light barrier properties of fish gelatin/agar bilayer film. LWT Food Sci. Technol. 2016, 71, 88-95. [CrossRef]

147. Rostamzad, H.; Paighambari, S.Y.; Shabanpour, B.; Ojagh, S.M.; Mousavi, S.M. Improvement of fish protein film with nanoclay and transglutaminase for food packaging. Food Packag. Shelf Life 2016, 7, 1-7. [CrossRef]

148. Davachi, S.M.; Shekarabi, A.S. Preparation and characterization of antibacterial, eco-friendly edible nanocomposite films containing Salvia macrosiphon and nanoclay. Int. J. Biol. Macromol. 2018, 113, 66-72. [CrossRef]

149. Cazón, P.; Velazquez, G.; Ramírez, J.A.; Vázquez, M. Polysaccharide-based films and coatings for food packaging: A review. Food Hydrocoll. 2017, 68, 136-148. [CrossRef] 
150. Shankar, S.; Rhim, J.-W. Preparation and characterization of agar/lignin/silver nanoparticles composite films with ultraviolet light barrier and antibacterial properties. Food Hydrocoll. 2017, 71, 76-84. [CrossRef]

151. Lomate, G.B.; Dandi, B.; Mishra, S. Development of antimicrobial LDPE/Cu nanocomposite food packaging film for extended shelf life of peda. Food Packag. Shelf Life 2018, 16, 211-219. [CrossRef]

152. Han, Y.; Yu, M.; Wang, L. Soy protein isolate nanocomposites reinforced with nanocellulose isolated from licorice residue: Water sensitivity and mechanical strength. Ind. Crops Prod. 2018, 117, 252-259. [CrossRef]

153. Ilyas, R.A.; Sapuan, S.M.; Ishak, M.R.; Zainudin, E.S. Development and characterization of sugar palm nanocrystalline cellulose reinforced sugar palm starch bionanocomposites. Carbohydr. Polym. 2018, 202, 186-202. [CrossRef]

154. Zahedi, Y.; Fathi-Achachlouei, B.; Yousefi, A.R. Physical and mechanical properties of hybrid montmorillonite/zinc oxide reinforced carboxymethyl cellulose nanocomposites. Int. J. Biol. Macromol. 2018, 108, 863-873. [CrossRef]

155. Rhim, J.-W. Effect of clay contents on mechanical and water vapor barrier properties of agar-based nanocomposite films. Carbohydr. Polym. 2011, 86, 691-699. [CrossRef]

156. Klangmuang, P.; Sothornvit, R. Combination of beeswax and nanoclay on barriers, sorption isotherm and mechanical properties of hydroxypropyl methylcellulose-based composite films. LWT Food Sci. Technol. 2016, 65, 222-227. [CrossRef]

157. Olivera, N.; Rouf, T.B.; Bonilla, J.C.; Carriazo, J.G.; Dianda, N.; Kokini, J.L. Effect of LAPONITE ${ }^{\circledR}$ addition on the mechanical, barrier and surface properties of novel biodegradable kafirin nanocomposite films. J. Food Eng. 2019, 245, 24-32. [CrossRef]

158. Valencia, G.A.; Luciano, C.G.; Lourenço, R.V.; Bittante, A.M.Q.B.; do Amaral Sobral, P.J. Morphological and physical properties of nano-biocomposite films based on collagen loaded with laponite ${ }^{\circledR}$. Food Packag. Shelf Life 2019, 19, 24-30. [CrossRef]

159. Rodríguez, F.J.; Galotto, M.J.; Guarda, A.; Bruna, J.E. Modification of cellulose acetate films using nanofillers based on organoclays. J. Food Eng. 2012, 110, 262-268. [CrossRef]

160. Shankar, S.; Teng, X.; Li, G.; Rhim, J.-W. Preparation, characterization, and antimicrobial activity of gelatin/ZnO nanocomposite films. Food Hydrocoll. 2015, 45, 264-271. [CrossRef]

161. Silva, J.M.; Barud, H.S.; Meneguin, A.B.; Constantino, V.R.L.; Ribeiro, S.J.L. Inorganic-organic bio-nanocomposite films based on Laponite and Cellulose Nanofibers (CNF). Appl. Clay Sci. 2019, 168, 428-435. [CrossRef]

162. Indumathi, M.P.; Saral Sarojini, K.; Rajarajeswari, G.R. Antimicrobial and biodegradable chitosan/cellulose acetate phthalate/ZnO nano composite films with optimal oxygen permeability and hydrophobicity for extending the shelf life of black grape fruits. Int. J. Biol. Macromol. 2019. [CrossRef]

163. Wu, Z.; Deng, W.; Luo, J.; Deng, D. Multifunctional nano-cellulose composite films with grape seed extracts and immobilized silver nanoparticles. Carbohydr. Polym. 2019, 205, 447-455. [CrossRef]

164. Sadegh-Hassani, F.; Mohammadi Nafchi, A. Preparation and characterization of bionanocomposite films based on potato starch/halloysite nanoclay. Int. J. Biol. Macromol. 2014, 67, 458-462. [CrossRef] [PubMed]

165. Franceschini, I.; Selmin, F.; Pagani, S.; Minghetti, P.; Cilurzo, F. Nanofiller for the mechanical reinforcement of maltodextrins orodispersible films. Carbohydr. Polym. 2016, 136, 676-681. [CrossRef] [PubMed]

166. Vaezi, K.; Asadpour, G.; Sharifi, H. Effect of ZnO nanoparticles on the mechanical, barrier and optical properties of thermoplastic cationic starch/montmorillonite biodegradable films. Int. J. Biol. Macromol. 2019, 124, 519-529. [CrossRef] [PubMed]

167. Wu, C.; Li, Y.; Du, Y.; Wang, L.; Tong, C.; Hu, Y.; Pang, J.; Yan, Z. Preparation and characterization of konjac glucomannan-based bionanocomposite film for active food packaging. Food Hydrocoll. 2019, 89, 682-690. [CrossRef]

168. Memiş, S.; Tornuk, F.; Bozkurt, F.; Durak, M.Z. Production and characterization of a new biodegradable fenugreek seed gum based active nanocomposite film reinforced with nanoclays. Int. J. Biol. Macromol. 2017, 103, 669-675. [CrossRef] [PubMed]

169. Nouri, A.; Yaraki, M.T.; Ghorbanpour, M.; Agarwal, S.; Gupta, V.K. Enhanced Antibacterial effect of chitosan film using Montmorillonite/CuO nanocomposite. Int. J. Biol. Macromol. 2018, 109, 1219-1231. [CrossRef] [PubMed] 
170. El Miri, N.; Abdelouahdi, K.; Barakat, A.; Zahouily, M.; Fihri, A.; Solhy, A.; El Achaby, M. Bio-nanocomposite films reinforced with cellulose nanocrystals: Rheology of film-forming solutions, transparency, water vapor barrier and tensile properties of films. Carbohydr. Polym. 2015, 129, 156-167. [CrossRef]

171. Farahnaky, A.; Dadfar, S.M.M.; Shahbazi, M. Physical and mechanical properties of gelatin-clay nanocomposite. J. Food Eng. 2014, 122, 78-83. [CrossRef]

172. Popescu, M.-C.; Dogaru, B.-I.; Goanta, M.; Timpu, D. Structural and morphological evaluation of CNC reinforced PVA/Starch biodegradable films. Int. J. Biol. Macromol. 2018, 116, 385-393. [CrossRef]

173. Arfat, Y.A.; Ahmed, J.; Hiremath, N.; Auras, R.; Joseph, A. Thermo-mechanical, rheological, structural and antimicrobial properties of bionanocomposite films based on fish skin gelatin and silver-copper nanoparticles. Food Hydrocoll. 2017, 62, 191-202. [CrossRef]

174. Marvizadeh, M.M.; Oladzadabbasabadi, N.; Mohammadi Nafchi, A.; Jokar, M. Preparation and characterization of bionanocomposite film based on tapioca starch/bovine gelatin/nanorod zinc oxide. Int. J. Biol. Macromol. 2017, 99, 1-7. [CrossRef]

175. Vicentini, N.; Gatti, T.; Salerno, M.; Hernandez Gomez, Y.S.; Bellon, M.; Gallio, S.; Marega, C.; Filippini, F.; Menna, E. Effect of different functionalized carbon nanostructures as fillers on the physical properties of biocompatible poly(l-lactic acid) composites. Mater. Chem. Phys. 2018, 214, 265-276. [CrossRef]

176. Ahmed, J.; Mulla, M.; Arfat, Y.A.; Thai T, L.A. Mechanical, thermal, structural and barrier properties of crab shell chitosan/graphene oxide composite films. Food Hydrocoll. 2017, 71, 141-148. [CrossRef]

177. Son, Y.-R.; Rhee, K.Y.; Park, S.-J. Influence of reduced graphene oxide on mechanical behaviors of sodium carboxymethyl cellulose. Compos. Part B Eng. 2015, 83, 36-42. [CrossRef]

178. El Achaby, M.; Kassab, Z.; Barakat, A.; Aboulkas, A. Alfa fibers as viable sustainable source for cellulose nanocrystals extraction: Application for improving the tensile properties of biopolymer nanocomposite films. Ind. Crops Prod. 2018, 112, 499-510. [CrossRef]

179. Kassab, Z.; Aziz, F.; Hannache, H.; Ben Youcef, H.; El Achaby, M. Improved mechanical properties of k-carrageenan-based nanocomposite films reinforced with cellulose nanocrystals. Int. J. Biol. Macromol. 2019, 123, 1248-1256. [CrossRef]

180. Kanmani, P.; Rhim, J.-W. Properties and characterization of bionanocomposite films prepared with various biopolymers and ZnO nanoparticles. Carbohydr. Polym. 2014, 106, 190-199. [CrossRef] [PubMed]

181. Mlalila, N.; Hilonga, A.; Swai, H.; Devlieghere, F.; Ragaert, P. Antimicrobial packaging based on starch, poly(3-hydroxybutyrate) and poly(lactic-co-glycolide) materials and application challenges. Trends Food Sci. Technol. 2018, 74, 1-11. [CrossRef]

182. Ma, Z.; Garrido-Maestu, A.; Jeong, K.C. Application, mode of action, and in vivo activity of chitosan and its micro- and nanoparticles as antimicrobial agents: A review. Carbohydr. Polym. 2017, 176, 257-265. [CrossRef] [PubMed]

183. Lu, C.; Brauer, M.J.; Botstein, D. Slow growth induces heat-shock resistance in normal and respiratory-deficient yeast. Mol. Biol. Cell 2009, 20, 891-903. [CrossRef] [PubMed]

184. Salari, M.; Sowti Khiabani, M.; Rezaei Mokarram, R.; Ghanbarzadeh, B.; Samadi Kafil, H. Development and evaluation of chitosan based active nanocomposite films containing bacterial cellulose nanocrystals and silver nanoparticles. Food Hydrocoll. 2018, 84, 414-423. [CrossRef]

185. Mohammadi Nafchi, A.; Moradpour, M.; Saeidi, M.; Alias, A.K. Effects of nanorod-rich ZnO on rheological, sorption isotherm, and physicochemical properties of bovine gelatin films. LWT Food Sci. Technol. 2014, 58, 142-149. [CrossRef]

186. Roy Choudhury, S.; Goswami, A. Supramolecular reactive sulphur nanoparticles: A novel and efficient antimicrobial agent. J. Appl. Microbiol. 2013, 114, 1-10. [CrossRef] [PubMed]

187. Besinis, A.; De Peralta, T.; Handy, R.D. The antibacterial effects of silver, titanium dioxide and silica dioxide nanoparticles compared to the dental disinfectant chlorhexidine on Streptococcus mutans using a suite of bioassays. Nanotoxicology 2014, 8, 1-16. [CrossRef] [PubMed]

188. Seil, J.T.; Webster, T.J. Antimicrobial applications of nanotechnology: Methods and literature. Int. J. Nanomed. 2012, 7, 2767-2781. [CrossRef]

189. Sothornvit, R.; Rhim, J.-W.; Hong, S.-I. Effect of nano-clay type on the physical and antimicrobial properties of whey protein isolate/clay composite films. J. Food Eng. 2009, 91, 468-473. [CrossRef]

190. Rhim, J.-W.; Hong, S.-I.; Ha, C.-S. Tensile, water vapor barrier and antimicrobial properties of PLA/nanoclay composite films. LWT Food Sci. Technol. 2009, 42, 612-617. [CrossRef] 
191. Giannakas, A.; Vlacha, M.; Salmas, C.; Leontiou, A.; Katapodis, P.; Stamatis, H.; Barkoula, N.-M.; Ladavos, A. Preparation, characterization, mechanical, barrier and antimicrobial properties of chitosan/PVOH/clay nanocomposites. Carbohydr. Polym. 2016, 140, 408-415. [CrossRef] [PubMed]

192. Shankar, S.; Reddy, J.P.; Rhim, J.-W.; Kim, H.-Y. Preparation, characterization, and antimicrobial activity of chitin nanofibrils reinforced carrageenan nanocomposite films. Carbohydr. Polym. 2015, 117, 468-475. [CrossRef] [PubMed]

193. Nafchi, A.M.; Alias, A.K.; Mahmud, S.; Robal, M. Antimicrobial, rheological, and physicochemical properties of sago starch films filled with nanorod-rich zinc oxide. J. Food Eng. 2012, 113, 511-519. [CrossRef]

194. Chen, J.; Wang, X.; Han, H. A new function of graphene oxide emerges: Inactivating phytopathogenic bacterium Xanthomonas oryzae pv. Oryzae. J. Nanoparticle Res. 2013, 15, 1658. [CrossRef]

195. Yousefi, M.; Dadashpour, M.; Hejazi, M.; Hasanzadeh, M.; Behnam, B.; de la Guardia, M.; Shadjou, N.; Mokhtarzadeh, A. Anti-bacterial activity of graphene oxide as a new weapon nanomaterial to combat multidrug-resistance bacteria. Mater. Sci. Eng. C 2017, 74, 568-581. [CrossRef] [PubMed]

196. Hu, X.; Jia, X.; Zhi, C.; Jin, Z.; Miao, M. Improving the properties of starch-based antimicrobial composite films using ZnO-chitosan nanoparticles. Carbohydr. Polym. 2019. [CrossRef] [PubMed]

197. Usman, A.; Hussain, Z.; Riaz, A.; Khan, A.N. Enhanced mechanical, thermal and antimicrobial properties of poly(vinyl alcohol)/graphene oxide/starch/silver nanocomposites films. Carbohydr. Polym. 2016, 153, 592-599. [CrossRef]

198. Pal, N.; Dubey, P.; Gopinath, P.; Pal, K. Combined effect of cellulose nanocrystal and reduced graphene oxide into poly-lactic acid matrix nanocomposite as a scaffold and its anti-bacterial activity. Int. J. Biol. Macromol. 2017, 95, 94-105. [CrossRef]

199. Kanmani, P.; Rhim, J.-W. Physicochemical properties of gelatin/silver nanoparticle antimicrobial composite films. Food Chem. 2014, 148, 162-169. [CrossRef]

200. Kumar, S.; Shukla, A.; Baul, P.P.; Mitra, A.; Halder, D. Biodegradable hybrid nanocomposites of chitosan/gelatin and silver nanoparticles for active food packaging applications. Food Packag. Shelf Life 2018, 16, 178-184. [CrossRef]

201. Shah, A.; Hussain, I.; Murtaza, G. Chemical synthesis and characterization of chitosan/silver nanocomposites films and their potential antibacterial activity. Int. J. Biol. Macromol. 2018, 116, 520-529. [CrossRef]

202. Lin, S.; Chen, L.; Huang, L.; Cao, S.; Luo, X.; Liu, K. Novel antimicrobial chitosan-cellulose composite films bioconjugated with silver nanoparticles. Ind. Crops Prod. 2015, 70, 395-403. [CrossRef]

203. Hajji, S.; Salem, R.B.S.-B.; Hamdi, M.; Jellouli, K.; Ayadi, W.; Nasri, M.; Boufi, S. Nanocomposite films based on chitosan-poly(vinyl alcohol) and silver nanoparticles with high antibacterial and antioxidant activities. Process Saf. Environ. Prot. 2017, 111, 112-121. [CrossRef]

204. Youssef, A.M.; Abdel-Aziz, M.S.; El-Sayed, S.M. Chitosan nanocomposite films based on Ag-NP and Au-NP biosynthesis by Bacillus Subtilis as packaging materials. Int. J. Biol. Macromol. 2014, 69, 185-191. [CrossRef]

205. Dairi, N.; Ferfera-Harrar, H.; Ramos, M.; Garrigós, M.C. Cellulose acetate/AgNPs-organoclay and/or thymol nano-biocomposite films with combined antimicrobial/antioxidant properties for active food packaging use. Int. J. Biol. Macromol. 2019, 121, 508-523. [CrossRef] [PubMed]

206. Sarwar, M.S.; Niazi, M.B.K.; Jahan, Z.; Ahmad, T.; Hussain, A. Preparation and characterization of PVA/nanocellulose/Ag nanocomposite films for antimicrobial food packaging. Carbohydr. Polym. 2018, 184, 453-464. [CrossRef] [PubMed]

207. Marín, T.; Montoya, P.; Arnache, O.; Pinal, R.; Calderón, J. Development of magnetite nanoparticles/gelatin composite films for triggering drug release by an external magnetic field. Mater. Des. 2018, 152, 78-87. [CrossRef]

208. Kloster, G.A.; Muraca, D.; Moscoso Londoño, O.; Knobel, M.; Marcovich, N.E.; Mosiewicki, M.A. Structural analysis of magnetic nanocomposites based on chitosan. Polym. Test. 2018, 72, 202-213. [CrossRef]

209. He, Q.; Zhang, Y.; Cai, X.; Wang, S. Fabrication of gelatin- $\mathrm{TiO}_{2}$ nanocomposite film and its structural, antibacterial and physical properties. Int. J. Biol. Macromol. 2016, 84, 153-160. [CrossRef]

210. Siripatrawan, U.; Kaewklin, P. Fabrication and characterization of chitosan-titanium dioxide nanocomposite film as ethylene scavenging and antimicrobial active food packaging. Food Hydrocoll. 2018, 84, 125-134. [CrossRef] 
211. Youssef, A.M.; El-Sayed, S.M.; El-Sayed, H.S.; Salama, H.H.; Dufresne, A. Enhancement of Egyptian soft white cheese shelf life using a novel chitosan/carboxymethyl cellulose/zinc oxide bionanocomposite film. Carbohydr. Polym. 2016, 151, 9-19. [CrossRef]

212. Qiu, B.; Xu, X.-F.; Deng, R.-H.; Xia, G.-Q.; Shang, X.-F.; Zhou, P.-H. Construction of chitosan/ZnO nanocomposite film by in situ precipitation. Int. J. Biol. Macromol. 2019, 122, 82-87. [CrossRef] [PubMed]

213. Saral Sarojini, K.; Indumathi, M.P.; Rajarajeswari, G.R. Mahua oil-based polyurethane/chitosan/nano ZnO composite films for biodegradable food packaging applications. Int. J. Biol. Macromol. 2019, 124, 163-174. [CrossRef]

214. Kumar, S.; Krishnakumar, B.; Sobral, A.J.F.N.; Koh, J. Bio-based (chitosan/PVA/ZnO) nanocomposites film: Thermally stable and photoluminescence material for removal of organic dye. Carbohydr. Polym. 2019, 205, 559-564. [CrossRef]

215. Oun, A.A.; Rhim, J.-W. Carrageenan-based hydrogels and films: Effect of $\mathrm{ZnO}$ and CuO nanoparticles on the physical, mechanical, and antimicrobial properties. Food Hydrocoll. 2017, 67, 45-53. [CrossRef]

216. Yadav, M. Study on thermal and mechanical properties of cellulose/iron oxide bionanocomposites film. Compos. Commun. 2018, 10,1-5. [CrossRef]

217. Swaroop, C.; Shukla, M. Mechanical, Optical and Antibacterial Properties of Polylactic Acid/Polyethylene Glycol Films Reinforced with MgO Nanoparticles. Mater. Today Proc. 2018, 5, 20711-20718. [CrossRef]

218. Jafarzadeh, S.; Ariffin, F.; Mahmud, S.; Alias, A.K.; Hosseini, S.F.; Ahmad, M. Improving the physical and protective functions of semolina films by embedding a blend nanofillers (ZnO-nr and nano-kaolin). Food Packag. Shelf Life 2017, 12, 66-75. [CrossRef]

219. Ejaz, M.; Arfat, Y.A.; Mulla, M.; Ahmed, J. Zinc oxide nanorods/clove essential oil incorporated Type B gelatin composite films and its applicability for shrimp packaging. Food Packag. Shelf Life 2018, 15, 113-121. [CrossRef]

220. Akbariazam, M.; Ahmadi, M.; Javadian, N.; Mohammadi Nafchi, A. Fabrication and characterization of soluble soybean polysaccharide and nanorod-rich $\mathrm{ZnO}$ bionanocomposite. Int. J. Biol. Macromol. 2016, 89, 369-375. [CrossRef]

221. Abutalib, M.M. Effect of zinc oxide nanorods on the structural, thermal, dielectric and electrical properties of polyvinyl alcohol/carboxymethyle cellulose composites. Phys. B Condensed Matter 2019, 557, 108-116. [CrossRef]

222. Perumal, A.B.; Sellamuthu, P.S.; Nambiar, R.B.; Sadiku, E.R. Development of polyvinyl alcohol/chitosan bio-nanocomposite films reinforced with cellulose nanocrystals isolated from rice straw. Appl. Surf. Sci. 2018, 449, 591-602. [CrossRef]

223. Mujtaba, M.; Salaberria, A.M.; Andres, M.A.; Kaya, M.; Gunyakti, A.; Labidi, J. Utilization of flax (Linum usitatissimum) cellulose nanocrystals as reinforcing material for chitosan films. Int. J. Biol. Macromol. 2017, 104, 944-952. [CrossRef] [PubMed]

224. Rong, S.Y.; Mubarak, N.M.; Tanjung, F.A. Structure-property relationship of cellulose nanowhiskers reinforced chitosan biocomposite films. J. Environ. Chem. Eng. 2017, 5, 6132-6136. [CrossRef]

225. Tang, Y.; Zhang, X.; Zhao, R.; Guo, D.; Zhang, J. Preparation and properties of chitosan/guar gum/nanocrystalline cellulose nanocomposite films. Carbohydr. Polym. 2018, 197, 128-136. [CrossRef] [PubMed]

226. Oun, A.A.; Rhim, J.-W. Preparation and characterization of sodium carboxymethyl cellulose/cotton linter cellulose nanofibril composite films. Carbohydr. Polym. 2015, 127, 101-109. [CrossRef]

227. El Achaby, M.; El Miri, N.; Hannache, H.; Gmouh, S.; Ben youcef, H.; Aboulkas, A. Production of cellulose nanocrystals from vine shoots and their use for the development of nanocomposite materials. Int. J. Biol. Macromol. 2018, 117, 592-600. [CrossRef] [PubMed]

228. González, A.; Gastelú, G.; Barrera, G.N.; Ribotta, P.D.; Álvarez Igarzabal, C.I. Preparation and characterization of soy protein films reinforced with cellulose nanofibers obtained from soybean by-products. Food Hydrocoll. 2019, 89, 758-764. [CrossRef]

229. Ma, X.; Cheng, Y.; Qin, X.; Guo, T.; Deng, J.; Liu, X. Hydrophilic modification of cellulose nanocrystals improves the physicochemical properties of cassava starch-based nanocomposite films. LWT 2017, 86, 318-326. [CrossRef]

230. Chi, K.; Catchmark, J.M. Improved eco-friendly barrier materials based on crystalline nanocellulose/chitosan/ carboxymethyl cellulose polyelectrolyte complexes. Food Hydrocoll. 2018, 80, 195-205. [CrossRef] 
231. Koosha, M.; Hamedi, S. Intelligent Chitosan/PVA nanocomposite films containing black carrot anthocyanin and bentonite nanoclays with improved mechanical, thermal and antibacterial properties. Prog. Org. Coat. 2019, 127, 338-347. [CrossRef]

232. Wang, L.-F.; Rhim, J.-W. Functionalization of halloysite nanotubes for the preparation of carboxymethyl cellulose-based nanocomposite films. Appl. Clay Sci. 2017, 150, 138-146. [CrossRef]

233. Biddeci, G.; Cavallaro, G.; Di Blasi, F.; Lazzara, G.; Massaro, M.; Milioto, S.; Parisi, F.; Riela, S.; Spinelli, G. Halloysite nanotubes loaded with peppermint essential oil as filler for functional biopolymer film. Carbohydr. Polym. 2016, 152, 548-557. [CrossRef] [PubMed]

234. Kanmani, P.; Rhim, J.-W. Physical, mechanical and antimicrobial properties of gelatin based active nanocomposite films containing AgNPs and nanoclay. Food Hydrocoll. 2014, 35, 644-652. [CrossRef]

235. Wang, H.; Wang, L.; Ye, S.; Song, X. Construction of Bi2WO6-TiO2/starch nanocomposite films for visible-light catalytic degradation of ethylene. Food Hydrocoll. 2019, 88, 92-100. [CrossRef]

236. Meira, S.M.M.; Zehetmeyer, G.; Scheibel, J.M.; Werner, J.O.; Brandelli, A. Starch-halloysite nanocomposites containing nisin: Characterization and inhibition of Listeria monocytogenes in soft cheese. LWT Food Sci. Technol. 2016, 68, 226-234. [CrossRef]

237. Wilpiszewska, K.; Antosik, A.K.; Spychaj, T. Novel hydrophilic carboxymethyl starch/montmorillonite nanocomposite films. Carbohydr. Polym. 2015, 128, 82-89. [CrossRef]

238. Abdollahi, M.; Alboofetileh, M.; Rezaei, M.; Behrooz, R. Comparing physico-mechanical and thermal properties of alginate nanocomposite films reinforced with organic and/or inorganic nanofillers. Food Hydrocoll. 2013, 32, 416-424. [CrossRef]

239. Mallakpour, S.; Nezamzadeh Ezhieh, A. Preparation and characterization of chitosan-poly(vinyl alcohol) nanocomposite films embedded with functionalized multi-walled carbon nanotube. Carbohydr. Polym. 2017, 166, 377-386. [CrossRef]

240. Bibi, S.; Jamil, A.; Yasin, T.; Rafiq, M.A.; Nawaz, M.; Price, G.J. Ultrasound promoted synthesis and properties of chitosan nanocomposites containing carbon nanotubes and silver nanoparticles. Eur. Polym. J. 2018, 105, 297-303. [CrossRef]

241. Ebrahimzadeh, S.; Ghanbarzadeh, B.; Hamishehkar, H. Physical properties of carboxymethyl cellulose based nano-biocomposites with Graphene nano-platelets. Int. J. Biol. Macromol. 2016, 84, 16-23. [CrossRef]

242. He, Y.; Wang, X.; Wu, D.; Gong, Q.; Qiu, H.; Liu, Y.; Wu, T.; Ma, J.; Gao, J. Biodegradable amylose films reinforced by graphene oxide and polyvinyl alcohol. Mater. Chem. Phys. 2013, 142, 1-11. [CrossRef]

243. Roy, S.; Rhim, J.-W. Preparation of carrageenan-based functional nanocomposite films incorporated with melanin nanoparticles. Colloids Surf. B Biointerfaces 2019, 176, 317-324. [CrossRef] [PubMed]

244. Yun, Y.-H.; Youn, H.-G.; Shin, J.-Y.; Yoon, S.-D. Preparation of functional chitosan-based nanocomposite films containing ZnS nanoparticles. Int. J. Biol. Macromol. 2017, 104, 1150-1157. [CrossRef] [PubMed]

245. Kundu, S.; Das, A.; Basu, A.; Abdullah, M.F.; Mukherjee, A. Guar gum benzoate nanoparticle reinforced gelatin films for enhanced thermal insulation, mechanical and antimicrobial properties. Carbohydr. Polym. 2017, 170, 89-98. [CrossRef] [PubMed]

246. Antoniou, J.; Liu, F.; Majeed, H.; Zhong, F. Characterization of tara gum edible films incorporated with bulk chitosan and chitosan nanoparticles: A comparative study. Food Hydrocoll. 2015, 44, 309-319. [CrossRef]

247. Yang, W.; Owczarek, J.S.; Fortunati, E.; Kozanecki, M.; Mazzaglia, A.; Balestra, G.M.; Kenny, J.M.; Torre, L.; Puglia, D. Antioxidant and antibacterial lignin nanoparticles in polyvinyl alcohol/chitosan films for active packaging. Ind. Crops Prod. 2016, 94, 800-811. [CrossRef]

248. Oun, A.A.; Rhim, J.-W. Effect of oxidized chitin nanocrystals isolated by ammonium persulfate method on the properties of carboxymethyl cellulose-based films. Carbohydr. Polym. 2017, 175, 712-720. [CrossRef]

249. Oun, A.A.; Rhim, J.-W. Preparation of multifunctional chitin nanowhiskers/ZnO-Ag NPs and their effect on the properties of carboxymethyl cellulose-based nanocomposite film. Carbohydr. Polym. 2017, 169, 467-479. [CrossRef]

250. Silva, N.H.C.S.; Vilela, C.; Almeida, A.; Marrucho, I.M.; Freire, C.S.R. Pullulan-based nanocomposite films for functional food packaging: Exploiting lysozyme nanofibers as antibacterial and antioxidant reinforcing additives. Food Hydrocoll. 2018, 77, 921-930. [CrossRef]

251. Banerjee, S.; Bagchi, B.; Bhandary, S.; Kool, A.; Hoque, N.A.; Biswas, P.; Pal, K.; Thakur, P.; Das, K.; Karmakar, P.; et al. Antimicrobial and biocompatible fluorescent hydroxyapatite-chitosan nanocomposite films for biomedical applications. Colloids Surf. B Biointerfaces 2018, 171, 300-307. [CrossRef] 
252. Gopi, S.; Amalraj, A.; Jude, S.; Thomas, S.; Guo, Q. Bionanocomposite films based on potato, tapioca starch and chitosan reinforced with cellulose nanofiber isolated from turmeric spent. J. Taiwan Inst. Chem. Eng. 2019. [CrossRef]

253. Rauscher, H.; Rasmussen, K.; Sokull-Klüttgen, B. Regulatory Aspects of Nanomaterials in the EU. Chemie Ingenieur Technik 2017, 89, 224-231. [CrossRef]

254. European Union (Ed.) Regulation (EU) No 528/2012 of the European Parliament and of the Council of 22 May 2012 Concerning the Making Available on the Market and Use of Biocidal Products; Official Journal of European Union: Brussels, Belgium, 2012; p. L167/161.

255. Luna-Martínez, J.F.; Hernández-Uresti, D.B.; Reyes-Melo, M.E.; Guerrero-Salazar, C.A.; González-González, V.A.; Sepúlveda-Guzmán, S. Synthesis and optical characterization of ZnS-sodium carboxymethyl cellulose nanocomposite films. Carbohydr. Polym. 2011, 84, 566-570. [CrossRef]

256. El-Wakil, N.A.; Hassan, E.A.; Abou-Zeid, R.E.; Dufresne, A. Development of wheat gluten/nanocellulose/ titanium dioxide nanocomposites for active food packaging. Carbohydr. Polym. 2015, 124, 337-346. [CrossRef]

257. Gorrasi, G.; Vertuccio, L. Evaluation of zein/halloysite nano-containers as reservoirs of active molecules for packaging applications: Preparation and analysis of physical properties. J. Cereal Sci. 2016, 70, 66-71. [CrossRef]

258. Motamedi, E.; Nasiri, J.; Malidarreh, T.R.; Kalantari, S.; Naghavi, M.R.; Safari, M. Performance of carnauba wax-nanoclay emulsion coatings on postharvest quality of 'Valencia' orange fruit. Sci. Hortic. 2018, 240, 170-178. [CrossRef]

259. Bott, J.; Störmer, A.; Franz, R. Migration of nanoparticles from plastic packaging materials containing carbon black into foodstuffs. Food Addit. Contam. Part A Chem. Anal. Control Expo. Risk Assess. 2014, 31, 1769-1782. [CrossRef]

260. Avella, M.; De Vlieger, J.J.; Errico, M.E.; Fischer, S.; Vacca, P.; Volpe, M.G. Biodegradable starch/clay nanocomposite films for food packaging applications. Food Chem. 2005, 93, 467-474. [CrossRef]

261. Abreu, A.S.; Oliveira, M.; de Sá, A.; Rodrigues, R.M.; Cerqueira, M.A.; Vicente, A.A.; Machado, A.V. Antimicrobial nanostructured starch based films for packaging. Carbohydr. Polym. 2015, 129, 127-134. [CrossRef] [PubMed]

262. Hu, J.; Kai, D.; Ye, H.; Tian, L.; Ding, X.; Ramakrishna, S.; Loh, X.J. Electrospinning of poly(glycerol sebacate)-based nanofibers for nerve tissue engineering. Mater. Sci. Eng. C Mater. Biol. Appl. 2017, 70, 1089-1094. [CrossRef]

263. Naseri-Nosar, M.; Farzamfar, S.; Sahrapeyma, H.; Ghorbani, S.; Bastami, F.; Vaez, A.; Salehi, M. Cerium oxide nanoparticle-containing poly ( $\varepsilon$-caprolactone)/gelatin electrospun film as a potential wound dressing material: In vitro and in vivo evaluation. Mater. Sci. Eng. C 2017, 81, 366-372. [CrossRef] [PubMed]

264. Tra Thanh, N.; Ho Hieu, M.; Tran Minh Phuong, N.; Do Bui Thuan, T.; Nguyen Thi Thu, H.; Thai, V.P.; Do Minh, T.; Nguyen Dai, H.; Vo, V.T.; Nguyen Thi, H. Optimization and characterization of electrospun polycaprolactone coated with gelatin-silver nanoparticles for wound healing application. Mater. Sci. Eng. C 2018, 91, 318-329. [CrossRef]

265. Ambrogi, V.; Pietrella, D.; Nocchetti, M.; Casagrande, S.; Moretti, V.; De Marco, S.; Ricci, M. Montmorillonite-chitosan-chlorhexidine composite films with antibiofilm activity and improved cytotoxicity for wound dressing. J. Colloid Interface Sci. 2017, 491, 265-272. [CrossRef] [PubMed]

266. Cacciotti, I.; Ciocci, M.; Di Giovanni, E.; Nanni, F.; Melino, S. Hydrogen Sulfide-Releasing Fibrous Membranes: Potential Patches for Stimulating Human Stem Cells Proliferation and Viability under Oxidative Stress. Int. J. Mol. Sci. 2018, 19. [CrossRef]

267. Wang, X.; Chang, J.; Wu, C. Bioactive inorganic/organic nanocomposites for wound healing. Appl. Mater. Today 2018, 11, 308-319. [CrossRef]

268. Jacob, J.; Haponiuk, J.T.; Thomas, S.; Gopi, S. Biopolymer based nanomaterials in drug delivery systems: A review. Mater. Today Chem. 2018, 9, 43-55. [CrossRef]

269. Javanbakht, S.; Namazi, H. Doxorubicin loaded carboxymethyl cellulose/graphene quantum dot nanocomposite hydrogel films as a potential anticancer drug delivery system. Mater. Sci. Eng. C 2018, 87, 50-59. [CrossRef] [PubMed]

270. Benucci, I.; Liburdi, K.; Cacciotti, I.; Lombardelli, C.; Zappino, M.; Nanni, F.; Esti, M. Chitosan/clay nanocomposite films as supports for enzyme immobilization: An innovative green approach for winemaking applications. Food Hydrocoll. 2018, 74, 124-131. [CrossRef] 
271. Stumpf, T.R.; Yang, X.; Zhang, J.; Cao, X. In situ and ex situ modifications of bacterial cellulose for applications in tissue engineering. Mater. Sci. Eng. C 2018, 82, 372-383. [CrossRef]

272. Hasan, A.; Waibhaw, G.; Saxena, V.; Pandey, L.M. Nano-biocomposite scaffolds of chitosan, carboxymethyl cellulose and silver nanoparticle modified cellulose nanowhiskers for bone tissue engineering applications. Int. J. Biol. Macromol. 2018, 111, 923-934. [CrossRef]

273. Kalishwaralal, K.; Jeyabharathi, S.; Sundar, K.; Selvamani, S.; Prasanna, M.; Muthukumaran, A. A novel biocompatible chitosan-Selenium nanoparticles (SeNPs) film with electrical conductivity for cardiac tissue engineering application. Mater. Sci. Eng. C 2018, 92, 151-160. [CrossRef]

274. Kalita, H.; Pal, P.; Dhara, S.; Pathak, A. Fabrication and characterization of polyvinyl alcohol/metal (Ca, Mg, Ti) doped zirconium phosphate nanocomposite films for scaffold-guided tissue engineering application. Mater. Sci. Eng. C 2017, 71, 363-371. [CrossRef]

275. Cacciotti, I. Cationic and Anionic Substitutions in Hydroxyapatite. In Handbook of Bioceramics and Biocomposites; Antoniac, I.V., Ed.; Springer International Publishing: Cham, Switzerland, 2016; pp. 145-211.

276. Nazeer, M.A.; Yilgör, E.; Yilgör, I. Intercalated chitosan/hydroxyapatite nanocomposites: Promising materials for bone tissue engineering applications. Carbohydr. Polym. 2017, 175, 38-46. [CrossRef]

277. Arumugam, R.; Subramanyam, V.; Chinnadurai, R.K.; Srinadhu, E.S.; Subramanian, B.; Nallani, S. Development of novel mechanically stable porous nanocomposite (PVDF-PMMA/HAp/TiO2) film scaffold with nanowhiskers surface morphology for bone repair applications. Mater. Lett. 2019, 236, 694-696. [CrossRef]

278. Bianco, A.; Bozzo, B.M.; Del Gaudio, C.; Cacciotti, I.; Armentano, I.; Dottori, M.; D’Angelo, F.; Martino, S.; Orlacchio, A.; Kenny, J.M. Poly (L-lactic acid)/calcium-deficient nanohydroxyapatite electrospun mats for bone marrow stem cell cultures. J. Bioact. Compat. Polym. 2011, 26, 225-241. [CrossRef]

279. D'Angelo, F.; Armentano, I.; Cacciotti, I.; Tiribuzi, R.; Quattrocelli, M.; Del Gaudio, C.; Fortunati, E.; Saino, E.; Caraffa, A.; Cerulli, G.G.; et al. Tuning Multi/Pluri-Potent Stem Cell Fate by Electrospun Poly(l-lactic acid)-Calcium-Deficient Hydroxyapatite Nanocomposite Mats. Biomacromolecules 2012, 13, 1350-1360. [CrossRef]

280. Ji, M.; Li, H.; Guo, H.; Xie, A.; Wang, S.; Huang, F.; Li, S.; Shen, Y.; He, J. A novel porous aspirin-loaded (GO/CTS-HA)n nanocomposite films: Synthesis and multifunction for bone tissue engineering. Carbohydr. Polym. 2016, 153, 124-132. [CrossRef]

281. You, Y.; Zhang, H.; Liu, Y.; Lei, B. Transparent sunlight conversion film based on carboxymethyl cellulose and carbon dots. Carbohydr. Polym. 2016, 151, 245-250. [CrossRef]

282. Mitta, S.B.; Reddeppa, M.; Vellampatti, S.; Dugasani, S.R.; Yoo, S.; Lee, S.; Kim, M.-D.; Ha Park, S. Gold nanoparticle-embedded DNA thin films for ultraviolet photodetectors. Sens. Actuators B Chem. 2018, 275, 137-144. [CrossRef]

(C) 2019 by the authors. Licensee MDPI, Basel, Switzerland. This article is an open access article distributed under the terms and conditions of the Creative Commons Attribution (CC BY) license (http://creativecommons.org/licenses/by/4.0/). 